\title{
Bio-optical properties and radiative energy budgets in fed and unfed scleractinian corals (Pocillopora sp.) during thermal bleaching
}

\author{
Niclas Heidelberg Lyndby ${ }^{1,2, *}$, Jacob Boiesen Holm ${ }^{1}$, Daniel Wangpraseurt ${ }^{1,3,4}$, \\ Christine Ferrier-Pagès ${ }^{5}$, Michael Kühl ${ }^{1,6}$
}

\footnotetext{
${ }^{1}$ Marine Biological Section, Department of Biology, University of Copenhagen, Strandpromenaden 5, 3000 Helsingør, Denmark ${ }^{2}$ Laboratory for Biological Geochemistry, School of Architecture, Civil and Environmental Engineering, Ecole Polytechnique Fédérale de Lausanne, 1015 Lausanne, Switzerland

${ }^{3}$ Department of Chemistry, University of Cambridge, CB2 1EW Cambridge, UK

${ }^{4}$ Scripps Institution of Oceanography, 9500 Gilman Drive, La Jolla, California 92093, USA ${ }^{5}$ Centre Scientifique de Monaco, Coral ecophysiology team, 8 Quai Antoine $1{ }^{\text {er }}, 98000$ Monaco ${ }^{6}$ Climate Change Cluster, University of Technology, Ultimo, NSW 2007, Australia
}

ABSTRACT: Corals live in symbiosis with algal dinoflagellates, which can achieve outstanding photosynthetic energy efficiencies in hospite approaching theoretical limits. However, how such photosynthetic efficiency varies with environmental stress remains poorly known. Using fiber-optic and electrochemical microsensors in combination with variable chlorophyll fluorescence imaging, we investigated the combined effects of thermal stress and active feeding on the radiative energy budget and photosynthetic efficiency of the symbiotic coral Pocillopora sp. At ambient temperature $\left(25^{\circ} \mathrm{C}\right)$, the percentage of absorbed light energy used for photosynthesis under low irradiance was higher for fed ( 5-6\%) compared to unfed corals $(4 \%)$. Corals from both feeding treatments responded equally to stress from high light exposure $(2400 \mu \mathrm{mol}$ photons $\mathrm{m}^{-2} \mathrm{~s}^{-1}$ ), exhibiting a decrease in photosynthetic efficiency, down to $0.5-0.6 \%$. Fed corals showed increased resilience to thermal-induced bleaching (loss of symbionts) compared to unfed corals. In addition, while unfed corals decreased their photosynthetic efficiency almost immediately when exposed to thermal stress, fed corals maintained a constant and high photosynthetic efficiency for 5 more days after onset of thermal stress. We conclude that active feeding is beneficial to corals by prolonging coral health and resilience during thermal stress as a result of an overall healthier symbiont population.

KEY WORDS: Coral bleaching $\cdot$ Feeding $\cdot$ Symbiosis $\cdot$ Microsensors $\cdot$ Light scattering $\cdot$ Photobiology

${ }^{*}$ Corresponding author: niclas.lyndby@epfl.ch

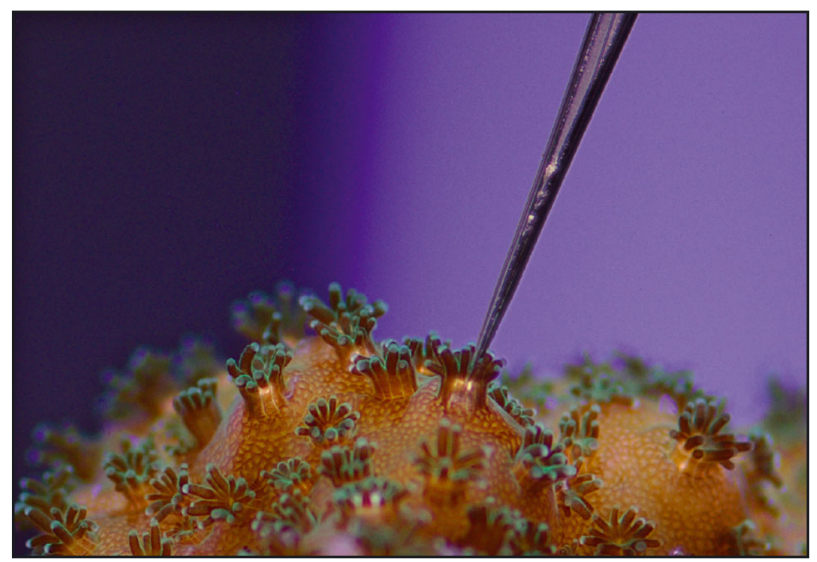

Microsensor measuring oxygen production at the base of a single polyp of Pocillopora damicornis.

Photo: Niclas H. Lyndby

\section{INTRODUCTION}

Tropical coral reefs are among the most diverse and productive ecosystems on Earth, although they occur in oligotrophic waters. The key drivers of reef formation are hermatypic scleractinian corals, which are fueled by various genera of endosymbiotic dinoflagellate microalgae belonging to the family Symbiodiniaceae (previously referred to as the single genus Symbiodinium; LaJeunesse et al. 2018). The coral holobiont, i.e. the association of the coral polyp 
with the Symbiodiniaceae and microbes in coral tissue and skeleton (Bourne et al. 2009), is able to acquire nutrients both via heterotrophy (e.g. prey capture; Houlbrèque \& Ferrier-Pagès 2009) and autotrophy (via symbiont photosynthesis and subsequent translocation of photosynthates from the symbionts to the host; Muscatine et al. 1981). While the dinoflagellate symbionts, i.e. zooxanthellae, only represent $\sim 5-15 \%$ of the coral tissue biomass (Odum \& Odum 1955, Thornhill et al. 2011), they provide up to $95 \%$ of the coral's energetic carbon demand (Muscatine et al. 1981, Edmunds \& Davies 1989). However, corals are susceptible to environmental stress (e.g. changes in seawater temperature, eutrophication, sedimentation or salinity), which can lead to the breakdown of the coral-algal symbiosis and the expulsion of the symbiotic algae, a phenomenon known as coral bleaching (Lesser 1996, Hoegh-Guldberg 1999, Hoegh-Guldberg et al. 2007, Wiedenmann et al. 2013).

Mass bleaching events have increased in frequency due to global climate change-derived heating of the ocean surface waters, which now represents a major threat to coral reefs worldwide (Hoegh-Guldberg 1999, Hughes et al. 2003, 2017, Ainsworth et al. 2016). On a larger scale, the most widely acknowledged stressors are instances of above-average sea water temperatures due to global warming, in combination with excess solar irradiance (Glynn 1996). The primary biochemical causes of coral bleaching are still debated (Brown \& Dunne 2015) but are strongly linked to the formation of reactive oxygen species (ROS) in corals upon environmental stress (Lesser 1996, Bou-Abdallah et al. 2006). Irradiance exposure plays a central role in the bleaching response of corals, and excess irradiance can lead to photodamage of photosystem II and essential repair systems in the zooxanthellae leading to the production of ROS (Lesser 1996, Lesser \& Farrell 2004, Hill et al. 2011). Nutrient starvation can also alter the lipid composition of algal membranes, leading to photodamage and reduced chlorophyll content and photosynthesis, especially at excess temperatures (Wiedenmann et al. 2013). However, heterotrophic feeding decreases coral bleaching susceptibility (Ferrier-Pagès et al. 2010). A better understanding of how corals handle light, and how nutrition interacts with light acquisition, is thus important for a mechanistic description of coral bleaching.

In reef environments, fluctuations in irradiance exposure (ranging from seconds to hours) create a need for regulating and optimizing light harvesting and utilization of incident light energy in symbiont- bearing corals (Anthony \& Hoegh-Guldberg 2003, Veal et al. 2010a). Photon absorption and the light microenvironment in corals are strongly modulated by the optical properties of the coral tissue and skeleton (Enriquez et al. 2005, Wangpraseurt et al. 2012, 2014a, Marcelino et al. 2013). The density and distribution of coral host pigments and symbionts in the tissue, as well as the scattering properties of both coral tissue and skeleton, are important factors for modulating symbiont light absorption and thus photosynthetic efficiency in hospite (Wangpraseurt et al. 2014b, 2019, Gittins et al. 2015, Lyndby et al. 2016). Photons traveling through coral tissue can undergo several scattering events, leading to localized scalar irradiance enhancement in upper tissue layers (Kühl et al. 1995, Wangpraseurt et al. 2012, 2017a). While such enhancement in light exposure contributes to high rates of photosynthesis of corals under optimal irradiance exposure (Brodersen et al. 2014), the same light-enhancing mechanisms can cause stress when corals are subject to excess irradiance, eventually resulting in coral bleaching. Enhanced skeletal scattering during bleaching leads to enhanced light absorption by the remaining dinoflagellate cells and can thus induce further light stress, ultimately accelerating the bleaching response, in a process known as the optical feedback loop (Enriquez et al. 2005, Wangpraseurt et al. 2017a).

Furthermore, the absorption of light energy is a major driver of radiative heat generation in coral tissue (Jimenez et al. 2012), with the rate of coral heating being directly proportional to the amount of incident light energy (Jimenez et al. 2008, Welch \& van Gemert 2011). Excess heat from the tissue is dissipated via convection into the surrounding water across a thermal boundary layer (TBL), and via heat conduction down into the coral skeleton (Jimenez et al. 2008). The thickness of the TBL changes depending on the ambient flow regime and coral topography (analogous to the well-known diffusive boundary layer, DBL), while the coral tissue surface area/ volume ratio affects overall coral surface warming and cooling (Jimenez et al. 2008, 2011). Coral surface topography thus affects the properties of the flowdependent DBL and TBL, ultimately controlling the exchange of solutes and heat (Lesser et al. 1994, Kaandorp et al. 1996, Jimenez et al. 2008, Chan et al. 2016).

Studies of photosynthetic efficiency and radiative energy budgets accounting for the fate of incident and absorbed light energy in benthic marine systems have so far focused on sediments, biofilms, 
and microbial mats (Al-Najjar et al. 2010, 2012, Lichtenberg et al. 2017), with the exception of a single study on a symbiont-bearing coral showing that light is used very efficiently for photosynthesis in corals (Brodersen et al. 2014). It was found that while the majority (>96\%) of incident light energy was absorbed and dissipated as heat, the local photosynthetic energy efficiency of zooxanthellae in the tissue of corals measured under low to moderate irradiance approached the theoretical maximum of $0.125 \mathrm{~mol} \mathrm{O}_{2}$ per mol photons. Furthermore, Brodersen et al. (2014) showed that as they increased the incident irradiance, the proportion of photosynthesis in the radiative energy budget decreased and heat dissipation increased, while reflectance (\%) remained unchanged at about $10 \%$ of the incident irradiance. Similar observations have been made in microbial mats, although these systems exhibit a much lower photosynthetic efficiency (Al-Najjar et al. 2010).

In this study, we investigated the closed radiative energy budgets in fed and unfed corals of Pocillopora sp. during thermal bleaching. This was based on detailed microsensor measurements of light, temperature and photosynthesis, and variable chlorophyll fluorescence imaging.

\section{MATERIALS AND METHODS}

\subsection{Corals}

Nubbins of Pocillopora sp. (presumed P. damicornis) were prepared by cutting 8 mother colonies into 128 fragments of $2-3 \mathrm{~cm}$ in diameter (16 fragments per colony), which were hung from nylon threads in several glass aquaria. Two months in advance of the bleaching experiment, the 16 fragments per colony were further divided into 8 fed or unfed nubbins, themselves equally divided into 4 fed and unfed tanks (2 nubbins per colony and per tank). All nubbins were kept under white light ( $250 \mathrm{~W}$ metal halide lamps), at a downwelling photon irradiance (400$700 \mathrm{~nm}$ ) of $250 \pm 20 \mu \mathrm{mol}$ photons $\mathrm{m}^{-2} \mathrm{~s}^{-1}$, illuminated for $12 \mathrm{~h} \mathrm{~d}^{-1}$. As aquaria were in transparent glass, and the set up was placed on a highly reflective white bench, light reaching the nubbins was not significantly different between the upper and lower side of the nubbins. Fed corals were fed once a day with $\sim 4000$ Artemia nauplii per coral fragment, 4 times per week, and unfed corals were heterotrophically starved throughout the study, including the 2 mo prior to measurements.
At the beginning of the study, all 8 tanks started at $25^{\circ} \mathrm{C}$. One tank per feeding treatment was then kept as a control, while the 3 other tanks were used for exposing corals to thermal stress by gradually ramping water temperature up to $30^{\circ} \mathrm{C}$ over a period of $5 \mathrm{~d}$, at a rate of $1^{\circ} \mathrm{C} \mathrm{d}^{-1}$. Thermally stressed corals were kept at $30^{\circ} \mathrm{C}$ for an additional 2 to $3 \mathrm{~d}$ before starting measurements. Corals measurements after 2-3 d of $30^{\circ} \mathrm{C}$ thermal stress are denoted as time point $1\left(\mathrm{~T}_{1}\right)$. After an additional $5 \mathrm{~d}$ of thermal stress, measurements were conducted again, denoted as time point $2\left(\mathrm{~T}_{2}\right)$. Measurements on control corals were done during the time period between $T_{1}$ and $\mathrm{T}_{2}$, and are denoted time point $0\left(\mathrm{~T}_{0}\right)$. No measurements were performed on unfed corals after $8 \mathrm{~d}$ of stress $\left(T_{2}\right)$ due to significant bleaching, which impaired measurements.

\subsection{Experimental setup and approach}

Microsensor measurements were performed on corals placed in a black acrylic flow chamber, which was supplied with seawater $\left(25^{\circ} \mathrm{C}\right.$, salinity $\left.35 \mathrm{ppt}\right)$ from a heated water reservoir (10 l) at a flow rate of $\sim 0.25 \mathrm{~cm} \mathrm{~s}^{-1}$. A motorized micromanipulator (MU-1, PyroScience) was attached to a heavy duty stand to facilitate positioning of microsensors on fragments at a $45^{\circ}$ angle relative to the vertically incident light. A digital microscope (Dino-Lite Edge AM7515MZTL, AnMo Electronics) was used for observation, while carefully positioning microsensor tips onto the coral tissue surface (Fig. 1e,f). Corals were illuminated from above with white light provided by a tungsten halogen lamp with an internal heat filter (KL-2500 LCD, Schott), fitted with a fiber light guide and a collimating lens (Fig. S1 in the Supplement at www. int-res.com/articles/suppl/m629p001_supp.pdf). A calibrated spectroradiometer (MSC-15, GigaHertz-Optik) was used to quantify the absolute downwelling photon irradiance (photosynthetically active radiation, PAR, 400-700 nm) at different lamp settings $(80,167$, $250,480,970$, and $2400 \mu \mathrm{mol}$ photons $\mathrm{m}^{-2} \mathrm{~s}^{-1}$ ), and to record downwelling irradiance spectra in units of $\mathrm{W} \mathrm{m} \mathrm{m}^{-2} \mathrm{~nm}^{-1}$. The irradiance was adjusted without changing spectral composition by adjusting a metal disk with varying perforation between the halogen light bulb and the fiber-optic light guide in the lamp light path. Setups were covered with black cloth during measurements to avoid stray light. For each coral replicate used in this study, microsensor measurements were done on 3 randomly chosen polyps located on the branch tips (Fig. 1). 


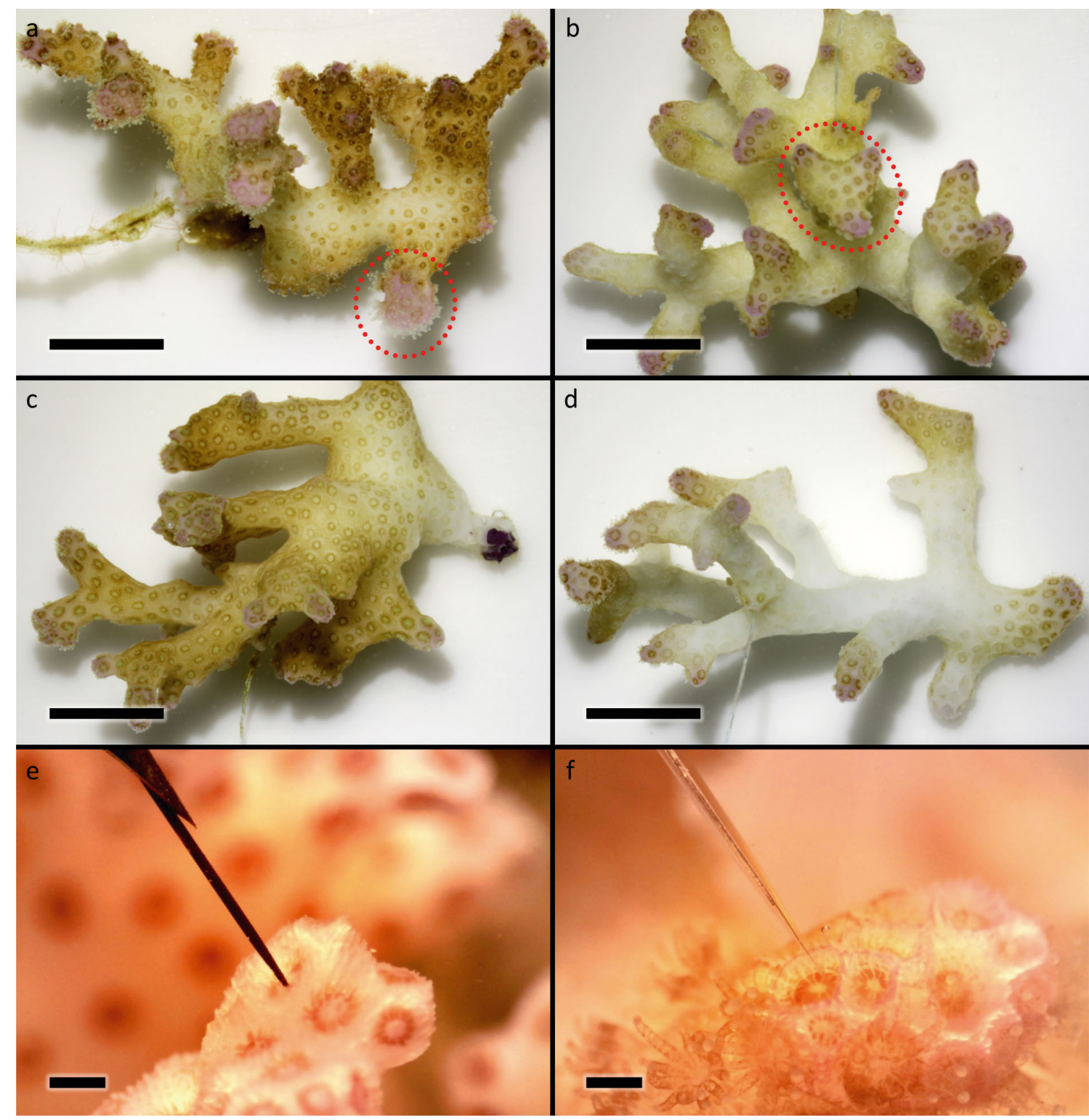

Fig. 1. Representative photographs of Pocillopora sp. corals subject to 4 experimental treatments: $(\mathrm{a}, \mathrm{b})$ controls and (c,d) thermally stressed fragments of fed $(\mathrm{a}, \mathrm{c})$ and unfed $(\mathrm{b}, \mathrm{d})$ Pocillopora sp. Photos were taken at the end of the experimental period, on the last day of measurements on unfed fragments $\left(\mathrm{T}_{1}\right)$. $(\mathrm{e}, \mathrm{f})$ Close-ups of measuring areas, with scalar irradiance $(\mathrm{e})$ and $\mathrm{O}_{2}$ (f) microsensors positioned on polyp tissue. The sensor tips were aimed at the highly pigmented polyp rims located at the branch tips of fragments. All photos were normalized against a white standard by adjusting the brightness/contrast levels using ImageJ. Note that the coral animal tissue structure was intact for all fragments. Sale bars $=1 \mathrm{~cm}$ (panels a-d) and $2.5 \mathrm{~mm}$ (panels e,f). Red dotted circles in panels a and $b$ indicate examples of areas used for microsensor measurements

\subsection{Microsensor measurements}

\subsubsection{Scalar irradiance and reflectance measurements}

Spectral scalar irradiance was measured with a fiber-optic scalar irradiance microsensor (spherical tip diameter $\sim 50 \mu \mathrm{m}_{i}$ Rickelt et al. 2016). Measurements were performed at the tissue surface and within the coral tissue for corals with tissue thicker than $50 \mu \mathrm{m}$. Tissue thick enough $(>50 \mu \mathrm{m})$ was carefully punctured with a tungsten needle (tip diameter $\sim 1 \mu \mathrm{m}$, see Wangpraseurt et al. 2017b for details), after which the sensor tip was quickly moved into the tissue. A reference spectrum of the incident downwelling irradiance was measured afterwards without the coral fragment and with the scalar irradiance microsensor tip placed over a black light well at the 
same position in the flow chamber and incident collimated light field as the coral surface.

Light reflection (arbitrary unit; counts) of the coral tissue surface was measured with a $0.7 \mathrm{~mm}$ wide flatcut fiber-optic probe positioned at a distance of $500 \mu \mathrm{m}$ from the tissue surface. To obtain the irradiance reflectance (in \% of incident irradiance), all measurements were normalized with the reflected light from a $99 \%$ white diffusing reflectance standard (Spectralon, Labsphere) measured under identical configuration to measurements at the coral surface but performed in air with the same distance from the tungsten halogen lamp (KL 2500, Schott).

Both scalar irradiance and reflectance microprobes were oriented at $45^{\circ}$ relative to the vertically incident light and were connected to a fiber-optic spectrometer (USB 2000+, Ocean Optics). All spectra were recorded with the software SpectraSuite (version 2.0. 162 , Ocean Optics) running on a PC connected to the spectrometer via a USB cable.

\subsubsection{Photosynthesis and $\mathrm{O}_{2}$ measurements}

Gross photosynthesis was measured with Clarktype $\mathrm{O}_{2}$ microelectrodes with a tip diameter of $\sim 25 \mu \mathrm{m}$, a low stirring sensitivity $(2-3 \%)$, and a fast response time $(<0.5 \mathrm{~s}$; OX-25 fast, Unisense). The microelectrodes were connected to a pA meter (Unisense), and were linearly calibrated from readings in $100 \%$ airsaturated seawater and anoxic water (by addition of $\mathrm{Na}_{2} \mathrm{SO}_{3}$ ) at experimental temperature and salinity. The corresponding $\mathrm{O}_{2}$ concentration $\left(\mu \mathrm{mol} \mathrm{l} \mathrm{l}^{-1}\right)$ in seawater at $100 \%$ air saturation was taken from gas tables for the $\mathrm{O}_{2}$ solubility in air-saturated water as a function of temperature and salinity (www.unisense .com). Data were recorded on a strip-chart recorder (BD25, Kipp\&Zonen) connected to the pA meter. Gross photosynthesis was estimated using the lightdark shift method as described in detail by Revsbech \& Jørgensen (1983), where the measurements performed at the coral tissue surface were regarded as representative of the entire tissue volume of Pocillopora sp. given that the tissue thickness in most places was less than 100-200 $\mu \mathrm{m}$, which approximates the spatial resolution of the light-dark shift method during the 2-3 s period of darkening. Accordingly, the areal rate of gross photosynthesis was estimated by multiplying the measured volume-specific gross photosynthesis at the tissue surface (in $\mathrm{nmol} \mathrm{O}_{2} \mathrm{~cm}^{-3}$ $\mathrm{s}^{-1}$ ) by the local tissue thickness (in $\mathrm{cm}$ ). The local tissue thickness was estimated from the difference in depth position of the scalar irradiance measure- ments done at the water-tissue and tissue-skeleton interface, respectively.

\subsubsection{Temperature measurements}

Coral tissue surface heating was measured with a temperature microsensor (tip diameter $\sim 50 \mu \mathrm{m}$; TP50, Unisense) connected to a thermocouple meter (T301, Unisense). The thermocouple meter was interfaced to a PC via an A/D converter (DCR 16, PyroScience) connected to a PC running the software Profix (version 4.51, PyroScience) that controlled the positioning of the micromanipulator and data acquisition. The temperature microsensor was linearly calibrated against a high-precision thermometer (Testo 110) in seawater at 19 and $25^{\circ} \mathrm{C}$. Temperature profiles were measured from the tissue surface into the ambient water in steps of 100-300 $\mu \mathrm{m}$ (with a resting time of $7 \mathrm{~s}$ at each depth position) across the TBL (Jimenez et al. 2008). The thickness of the TBL was determined as the intersection of the linear part of the temperature profile and the ambient water (cf. Fig. 1b in Jimenez et al. 2008). $\Delta \mathrm{T}$ was determined as the temperature difference in ${ }^{\circ} \mathrm{C}$ between the coral surface and ambient water outside the TBL (i.e. $5 \mathrm{~mm}$ above the tissue surface). All temperature measurements were done under a high incident photon irradiance (400-700 nm) of $2400 \mu \mathrm{mol}$ photons $\mathrm{m}^{-2} \mathrm{~s}^{-1}$.

\subsection{Chlorophyll content and symbiont density}

Chlorophyll $a+C_{2}$ content and symbiont density were determined for 4-5 coral fragments from each treatment at each time point. For this, tissue was first detached using a Water Pick with filtered seawater (FSW, $0.45 \mu \mathrm{m}$ pore size). The tissue slurry was then homogenized using a Potter tissue grinder. For chlorophyll content determination, $5 \mathrm{ml}$ of the homogenate were centrifuged at $11000 \times g\left(15 \mathrm{~min}\right.$ at $\left.4^{\circ} \mathrm{C}\right)$; the supernatant was discarded and the remaining algal pellet was re-suspended in $5 \mathrm{ml}$ of pure acetone. Pigments were extracted at $4^{\circ} \mathrm{C}$ over a period of $24 \mathrm{~h}$ in darkness, before they were centrifuged. The pigment-containing supernatant was collected, and the chlorophyll content was determined by the spectrophotometric method of Jeffrey \& Humphrey (1975) using a spectrophotometer (UVmc2, Safas).

The density of Cladocopium sp. (formerly Symbiodinium clade $\mathrm{C}_{i}$ LaJeunesse et al. 2018) was determined by centrifugation of $0.1 \mathrm{ml}$ of the tissue homogenate at $850 \times g(10 \mathrm{~min})$. The supernatant was 
discarded, and the algal pellet was re-suspended in FSW that was subsequently used for 10 separate chamber counts. Cladocopium sp. were counted according to the method described by Rodolfo-Metalpa et al. (2006) using image analysis software (Histolab 5.2.3, Microvision Instruments).

Values of chlorophyll content and symbiont density were normalized against the skeleton surface area of the individual coral fragments as determined by the wax dipping method described by Veal et al. (2010b).

\subsection{Imaging of variable chlorophyll fluorescence and absorptivity}

The absorptivity and PSII quantum yield of randomly selected fragments from both control tanks $T_{0}$, unfed $T_{1}$, and fed $T_{2}$ were measured using a variable chlorophyll fluorescence imaging system using red measuring and actinic light (I-PAM, IMAG-MIN/R, Walz; Ralph et al. 2005). The measuring light intensity was adjusted for each measurement to yield an $F_{0}$ value (see Table 1 ) of about 0.1 for each sample.

Data were collected by placing 3-4 fragments from one treatment and time point in a clear glass container filled with seawater from the holding tank. Fragments were dark-acclimated for $15 \mathrm{~min}$ in seawater tanks covered with dark cloths before transfer in dim light to the PAM fluorometer followed by 5 min of further dark acclimation. After a total of 20 min of dark acclimation, the maximal PSII quantum yield $\left(F_{\mathrm{v}} / F_{\mathrm{m}}\right)$ was measured by applying a strong saturation pulse $\left(>3000 \mu \mathrm{mol}\right.$ photons $\mathrm{m}^{-2} \mathrm{~s}^{-1}$ for $0.8 \mathrm{~s}$ ) with the imaging PAM:

$$
F_{\mathrm{v}} / F_{\mathrm{m}}=\left(F_{\mathrm{m}}-F_{0}\right) / F_{\mathrm{m}}
$$

where $F_{0}$ denotes the minimum fluorescent yield under dark acclimation, and $F_{\mathrm{m}}$ denotes the maximal fluorescent yield under complete closure of PSII during the saturation pulse.

Rapid light curves (RLCs) were measured for actinic light intensities ranging between 0 and $1600 \mu \mathrm{mol}$ photons $\mathrm{m}^{-2} \mathrm{~s}^{-1}$. For each RLC, corals were exposed to a total of 14 light intensities $(12,40,73,99,132$, 162, 190, 292, 437, 606, 853, 1177, 1631 umol photons $\mathrm{m}^{-2} \mathrm{~s}^{-1}$ ) for $10 \mathrm{~s}$ at each light intensity. The effective PSII quantum yield, $Y($ II), quantum yield of regulated energy dissipation, $Y(\mathrm{NPQ})$, and quantum yield of nonregulated energy dissipation, $Y(\mathrm{NO})$, were calculated as:

$$
Y(\mathrm{II})=\left(F_{\mathrm{m}}{ }^{\prime}-F\right) / F_{\mathrm{m}}{ }^{\prime}
$$

$$
\begin{gathered}
Y(\mathrm{NPQ})=1-Y(\mathrm{II})-1 /\left[\mathrm{NPQ}+1+q L\left(F_{\mathrm{m}} / F_{0}-1\right)\right] \\
Y(\mathrm{NO})=1 /\left[\mathrm{NPQ}+1+q L\left(F_{\mathrm{m}} / F_{0}-1\right)\right] \\
Y(\mathrm{II})+Y(\mathrm{NPQ})+Y(\mathrm{NO})=1
\end{gathered}
$$

where $F$ denotes the fluorescent yield in the presence of actinic light, $F_{\mathrm{m}}$ ' denotes the maximum fluorescent yield during a saturation pulse, and $q L$ is the fraction of PSII reaction centers that are open. See Hill et al. (2004) and Baker (2008) for more details on variable chlorophyll fluorimetry. Calculations were performed for defined tissue areas by selecting regions of interest using the software ImagingWin (v2.41a, Walz). See Table 1 for definitions of parameters used.

\subsection{Radiative energy budget calculations}

The radiative energy budget was calculated following procedures described in detail by Al-Najjar et al. (2010) but with minor changes as described below. The absolute downwelling spectral irradiance (in $\mathrm{W} \mathrm{m}^{-2} \mathrm{~nm}^{-1}$ ) was measured with a calibrated spectroradiometer (MSC15, GigaHertz-Optik) and integrated over 400-700 nm (PAR) to quantify the total incident radiant energy flux of $\operatorname{PAR}\left(J_{\mathrm{IN}}, \mathrm{J} \mathrm{m}^{-2} \mathrm{~s}^{-1}\right)$.

From $J_{\text {IN }}$, we estimated the proportion of light energy absorbed $\left(J_{\text {abs }}\right)$ and reflected $(R)$ by the coral. The PAR irradiance reflectance $\left(\% ; R_{(\mathrm{PAR})}\right)$ was calculated as:

$$
R_{(\mathrm{PAR})}=R_{\mathrm{t}} / R_{\mathrm{ws}}
$$

where $R_{\mathrm{t}}$ is the reflected light from coral tissue, and $R_{\mathrm{ws}}$ is the reflected light measured from a $99 \%$ white diffusing standard (Spectralon, Labsphere). The upwelling reflected light energy $\left(R_{;}\right.$in $\left.\mathrm{J} \mathrm{m}^{-2} \mathrm{~s}^{-1}\right)$ was calculated as:

Table 1. Definitions of parameters used for imaging of variable chlorophyll fluorescence

\begin{tabular}{|ll|}
\hline Parameter & Definition \\
\hline$F_{\mathrm{m}}$ & Maximal fluorescence yield (dark adapted) \\
$F_{0}$ & Minimal fluorescence yield (dark adapted) \\
$F_{\mathrm{v}} / F_{\mathrm{m}}$ & Maximal PSII quantum yield \\
$F_{\mathrm{m}}{ }^{\prime}$ & Maximum fluorescence yield (light \\
& acclimated) \\
$F$ & Fluorescence yield (light acclimated) \\
$q L$ & Fraction of PSII centers that are open \\
$Y(\mathrm{II})$ & Effective PSII quantum yield \\
$Y(\mathrm{NPQ})$ & Quantum yield of regulated energy \\
& dissipation \\
$Y(\mathrm{NO})$ & Quantum yield of nonregulated energy \\
& dissipation \\
\hline
\end{tabular}




$$
R=J_{\mathrm{IN}} \times R_{(\mathrm{PAR})}
$$

The light energy absorbed by the coral tissue, $J_{\text {abs }}$ (in $\mathrm{J} \mathrm{m}^{-2} \mathrm{~s}^{-1}$ ), was then calculated as the vector irradiance:

$$
J_{\mathrm{abs}}=J_{\mathrm{IN}} \times\left(1-R_{(\mathrm{PAR})}\right)
$$

The absorbed light energy in the coral is either dissipated as heat, $J_{\mathrm{H}}$, or conserved by photosynthesis, $J_{\mathrm{PS}}$. The energy conserved by photosynthesis was estimated by recalculating the measured areal gross photosynthesis, GPP, in energy units by multiplication with the Gibbs free energy, $E_{\mathrm{G}}=482.9 \mathrm{~kJ}$ $(\mathrm{mol} \mathrm{O})^{-1}$, i.e. the amount of energy produced during oxygenic photosynthesis (Al-Najjar et al. 2010). The total amount of energy conserved by photosynthesis, $J_{\mathrm{PS}}\left(\right.$ in $\mathrm{J} \mathrm{m}^{-2} \mathrm{~s}^{-1}$ ) was thus calculated as:

$$
J_{\mathrm{PS}}=\mathrm{GPP} \times E_{\mathrm{G}}
$$

The remaining part of the absorbed light was dissipated as heat, $J_{\mathrm{H}}$, via an upward heat flux across the TBL or via a downward heat flux into the coral skeleton (Jimenez et al. 2008). The upward heat flux, $J_{\mathrm{H} \text {-up }}$ was calculated from temperature microsensor measurements across the TBL, using the linear slope of the temperature profile $\left(\mathrm{K} \mathrm{m}^{-1}\right)$ over the coral tissue surface, and multiplying it with the thermal conductivity of seawater at a salinity of $35 \mathrm{ppt}, k=0.6 \mathrm{~W} \mathrm{~m}^{-1} \mathrm{~K}^{-1}$ :

$$
J_{\text {H-up }}=k \frac{\mathrm{d} T}{\mathrm{~d} z}
$$

where $T$ is the temperature measured in Kelvin, and $z$ is the distance measured in $\mathrm{m}$. It was not possible to directly measure the heat conduction from tissue into the coral skeleton with the fragile temperature microsensors, and the downward heat flux, $J_{\mathrm{H} \text {-down }}\left(\right.$ in $\mathrm{J} \mathrm{m}^{-2} \mathrm{~s}^{-1}$ ) was thus estimated as:

$$
J_{\mathrm{H}-\text { down }}=J_{\mathrm{abs}}-\left(J_{\mathrm{H}-\mathrm{up}}+J_{\mathrm{PS}}\right)
$$

The total amount of energy dissipated as heat in the coral, $J_{\mathrm{H}}$ (in $\mathrm{J} \mathrm{m}^{-2}$ $\mathrm{s}^{-1}$ ), was then calculated as:

$$
J_{\mathrm{H}}=J_{\mathrm{H}-\text { up }}-J_{\mathrm{H}-\text { down }}
$$

The entire radiative energy budget (in $\mathrm{J} \mathrm{m}^{-2} \mathrm{~s}^{-1}$ ) is thus found as:

$$
J_{\mathrm{IN}}=J_{\mathrm{abs}}-R=J_{\mathrm{PS}}+J_{\mathrm{H}}-R
$$

Energy budgets at lower irradiances were calculated based on detailed gross photosynthesis measurements on fragments from all time points
$\left(\mathrm{T}_{0}-\mathrm{T}_{2}\right)$ at previously mentioned photon irradiances (see Section 2.2). The detailed measurements were combined with temperature and reflectance data, based on the assumption of a positive linear relationship between incident downwelling photon irradiance and heat dissipation (Jimenez et al. 2008), and a near-constant percentage of reflection from the coral surface regardless of the incident irradiance (Al-Najjar et al. 2010, Brodersen et al. 2014). See Table 2 for definitions and units of abbreviations and parameters used.

\section{RESULTS}

\subsection{Variable chlorophyll fluorescence imaging}

The effective PSII quantum yield, $Y(\mathrm{II})$, at the incident downwelling irradiance $\left(E_{d}=1630 \mu \mathrm{mol}\right.$ photons $\mathrm{m}^{-2} \mathrm{~s}^{-1}$ ) in unfed corals did not change over time from $\left(T_{0}\right)$ and during thermal stress $\left(T_{1}\right)$, while fed corals showed a significant 3.2-fold increase of $Y(\mathrm{II})$ after $8 \mathrm{~d}$ at $30^{\circ} \mathrm{C}\left(\mathrm{T}_{2}\right)$ relative to the control treatment (ANOVA, $F_{1,46}=12.7, \mathrm{p} \ll 0.01$; Fig. 2a). Overall, fed corals presented a higher $Y($ II) than unfed corals during all measurements (Fig. 2a).

The maximal relative PS electron transport rate, rETR, at the highest photon irradiance $\left(E_{d}=1630\right.$

\begin{tabular}{|c|c|c|}
\hline Abbreviation & Definition & Unit \\
\hline PAR & $\begin{array}{l}\text { Photosynthetically active radiation } \\
(400-700 \mathrm{~nm})\end{array}$ & N/A \\
\hline TBL & Thermal boundary layer & N/A \\
\hline$R_{\mathrm{t}}$ & Tissue reflected light & Arbitrary unit \\
\hline$R_{\mathrm{ws}}$ & $\begin{array}{l}\text { Reflected light from white standard } \\
\text { reflectance }\end{array}$ & Arbitrary unit \\
\hline$R_{(\mathrm{PAR})}$ & PAR irradiance reflectance $\left(R_{\mathrm{t}} / R_{\mathrm{ws}}\right)$ & Arbitrary unit \\
\hline$J_{\text {IN }}$ & Downwelling irradiance in energy units & $\mathrm{J} \mathrm{m}^{-2} \mathrm{~s}^{-1}$ \\
\hline$R$ & Reflected light energy & $\mathrm{J} \mathrm{m}^{-2} \mathrm{~s}^{-1}$ \\
\hline$J_{\text {abs }}$ & Absorbed light energy & $\mathrm{J} \mathrm{m}^{-2} \mathrm{~s}^{-1}$ \\
\hline GPP & Areal rate of gross primary production & $\mathrm{nmol} \mathrm{O} \mathrm{Cm}^{-2} \mathrm{~s}^{-1}$ \\
\hline$E_{\mathrm{G}}$ & Gibbs energy & $\mathrm{kJ}\left(\mathrm{mol} \mathrm{O}_{2}\right)^{-1}$ \\
\hline$J_{\mathrm{PS}}$ & Energy conserved by photosynthesis & $\mathrm{J} \mathrm{m}^{-2} \mathrm{~s}^{-1}$ \\
\hline$k$ & Thermal conductivity of seawater & $\mathrm{W} \mathrm{m}^{-1} \mathrm{~K}^{-1}$ \\
\hline $\mathrm{d} T / \mathrm{d} z$ & Temperature gradient in the TBL & $\mathrm{K} \mu \mathrm{m}^{-1}$ \\
\hline$J_{\text {H-up }}$ & Upward heat flux in energy units & $\mathrm{J} \mathrm{m}^{-2} \mathrm{~s}^{-1}$ \\
\hline$J_{\text {H-down }}$ & Downward heat flux in energy units & $\mathrm{J} \mathrm{m}^{-2} \mathrm{~s}^{-1}$ \\
\hline$J_{\mathrm{H}}$ & Total heat flux in energy units & $\mathrm{J} \mathrm{m}^{-2} \mathrm{~s}^{-1}$ \\
\hline
\end{tabular}
umol photons $\mathrm{m}^{-2} \mathrm{~s}^{-1}$ ) did not differ between unfed corals before $\left(T_{0}\right)$ and after thermal stress $\left(T_{1}\right)$, while fed corals showed a significant 1.6-fold increase in rETR after $8 \mathrm{~d}$ at $30^{\circ} \mathrm{C}\left(\mathrm{T}_{2}\right)$ relative to the

Table 2. Abbreviations, definitions, and units used for the radiative energy budget calculations. N/A: not applicable 


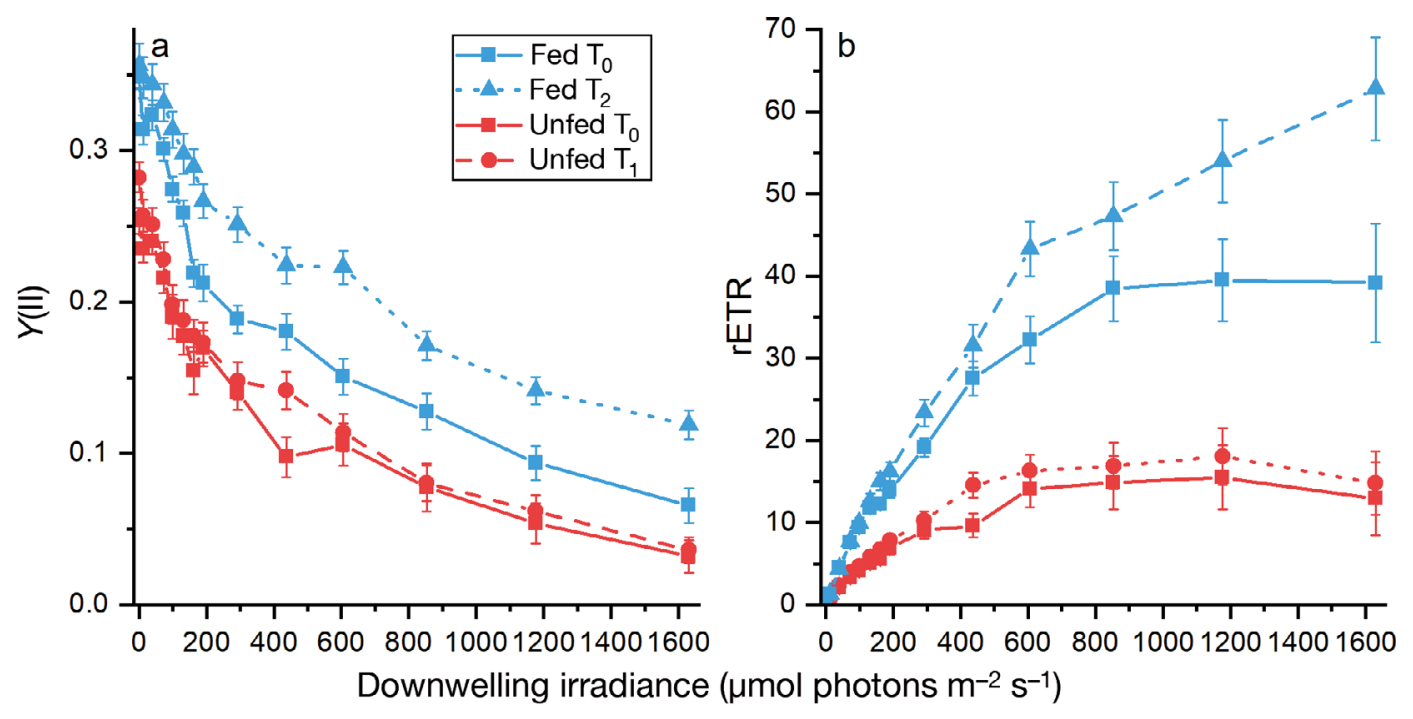

Fig. 2. Variable chlorophyll fluorescence imaging of polyp tissue in fed and unfed Pocillopora sp. during thermal stress treatment. (a) Effective PSII quantum yield [ $Y(\mathrm{II})]$, and (b) relative electron transport rate (rETR) before ( $\mathrm{T}_{0}$ ) and after thermal stress $\left(\mathrm{T}_{1}-\mathrm{T}_{2}\right)$. Symbols with error bars indicate means $\pm \mathrm{SE}$ of $Y(\mathrm{II})$ and $\mathrm{rETR}$ in different areas of interest in the images $(\mathrm{n}=24-36)$

control ( $\mathrm{T}_{0}$, ANOVA, $F_{1,46}=6.1, \mathrm{p}=0.02$; Fig. $\left.2 \mathrm{~b}\right)$. The rETR of fed corals was also 2-fold higher than the rETR of unfed corals, at both $\mathrm{T}_{0}$ and $\mathrm{T}_{1}$, and all light levels, which is in agreement with a higher $F_{\mathrm{v}} / F_{\mathrm{m}}\left(\right.$ ANOVA, $F_{1,106}=44.3, \mathrm{p}<0.01$; see $F_{\mathrm{v}} / F_{\mathrm{m}}$ data in Fig. S2).

\subsection{Chlorophyll content and symbiont density}

Cladocopium sp. cell density at $\mathrm{T}_{0}$ was about 1.9 times higher for fed fragments compared to unfed fragments (ANOVA, $F_{1,7}=74.8, \mathrm{p}<<0.01$ ), and cell density decreased steadily in corals under both feeding treatments during thermal stress $\left(\mathrm{T}_{1}-\mathrm{T}_{2}\right.$, Fig. 3a). Relative to the starting population at $\mathrm{T}_{0}$, cell density loss in fed fragments was $10.1 \%$ after $3 \mathrm{~d}$ at $30^{\circ} \mathrm{C}\left(\mathrm{T}_{1}\right)$, and $27.5 \%$ after $8 \mathrm{~d}$ at $30^{\circ} \mathrm{C}\left(\mathrm{T}_{2}\right.$; ANOVA, $F_{2,11}=6.2$, $\mathrm{p}=0.016$ ). For unfed fragments, cell density loss was $23.4 \%$ after $3 \mathrm{~d}$ at $30^{\circ} \mathrm{C}\left(\mathrm{T}_{1}\right)$, relative to the starting population (ANOVA, $F_{1,7}=9.1, p=0.020$; Fig. 3a). The chlorophyll content per area $\left(\mu \mathrm{g} \mathrm{cm}^{-2}\right)$ was about 3.4 times higher in fed fragments as compared to unfed fragments at $\mathrm{T}_{0}$ (ANOVA, $F_{1,21}=17.8, \mathrm{p}<<$ 0.01). No significant changes in chlorophyll $\left(\mu \mathrm{g} \mathrm{cm}^{-2}\right)$ were observed during thermal stress in fragments from both feeding treatments relative to the starting content $\left(\mathrm{T}_{0}-\mathrm{T}_{2}\right.$; ANOVA, $F_{2,11}=0.8, \mathrm{p}=0.49$ for fed, $F_{1,7}=0.3, \mathrm{p}=0.61$; Fig. $\left.3 \mathrm{~b}\right)$.

Chlorophyll content per cell was not affected by thermal stress relative to the starting content, but was on average 1.8 times higher in Cladocopium sp. from fed fragments compared to Cladocopium sp. from unfed fragments across all time points $\left(\mathrm{T}_{0}-\mathrm{T}_{2}\right.$; ANOVA, $F_{1,3}=49.1, \mathrm{p}<0.01$; Fig. 3c).

\subsection{Scalar irradiance}

Coral tissue surface photon scalar irradiance (425$700 \mathrm{~nm})$ at $\mathrm{T}_{0}$ was $122.7 \pm 0.07 \%$ (mean $\pm \mathrm{SE}$ ) of the incident downwelling photon irradiance $\left(\mathrm{E}_{\mathrm{d}}=2400 \mu \mathrm{mol}\right.$ photons $\mathrm{m}^{-2} \mathrm{~s}^{-1}$ ) pooled across fed and unfed corals with no significant difference between the 2 groups (ANOVA, $F_{1,25}=0.24, p=0.63$; Fig. 4a). Enhancement of tissue surface scalar irradiance peaked after $3 \mathrm{~d}$ at $30^{\circ} \mathrm{C}\left(\mathrm{T}_{1}\right)$ in both treatments, reaching a pooled photon scalar irradiance of $143.7 \pm 0.07 \%$ for both fed and unfed corals relative to $\mathrm{E}_{\mathrm{d}}$, with no significant differences (ANOVA, $F_{1,19}=0.16, \mathrm{p}=0.69$; Fig. 4a). At $\mathrm{T}_{0}$, scalar irradiance at the coral tissue-skeleton interface was $98.7 \pm 0.06 \%$ of the incident downwelling irradiance pooled across fed and unfed corals with no significant difference between the 2 groups (ANOVA, $F_{1,23}=0.51, \mathrm{p}=0.48$; Fig. $4 \mathrm{~b}$ ). Scalar irradiance at the tissue-skeleton interface did not change with thermal stress $\left(\mathrm{T}_{1}-\mathrm{T}_{2}\right)$ relative to $\mathrm{T}_{0}$ (ANOVA, $F_{2,34}=1.5, \mathrm{p}=0.24$ for fed, $F_{1,21}=2.8, \mathrm{p}=0.19$ for unfed; Fig. 4b).

A distinct spectral attenuation was observed in the near infrared part of the spectrum (700-750 nm) at the tissue-skeleton interface in unfed corals after $3 \mathrm{~d}$ at $30^{\circ} \mathrm{C}\left(\mathrm{T}_{1}\right)$, and in fed corals after $8 \mathrm{~d}$ at $30^{\circ} \mathrm{C}\left(\mathrm{T}_{2}\right.$; Fig. 4e,f), suggestive of the presence of endoliths in the coral skeleton, but no such endoliths were perceivable to the naked eye (see Section 4.1). 


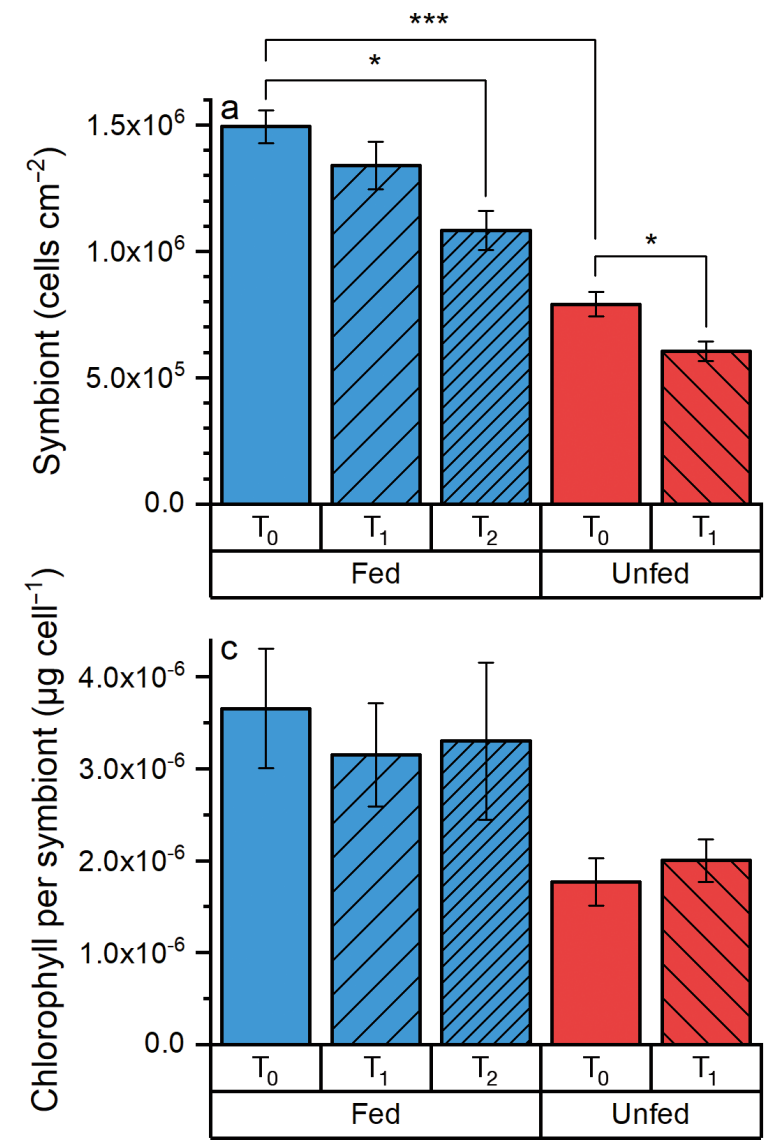

\subsection{Reflectance measurements}

Spectral reflectance (\%) of PAR (400-700 nm) was $11.7 \pm 0.009(\mathrm{SE}) \%$ and $15.5 \pm 0.007 \%$ at $\mathrm{T}_{0}$ for fed and unfed fragments of Pocillopora sp., respectively (Fig. 5a). Fed coral fragments showed a significantly increased reflectance $(\%)$ at $\mathrm{T}_{2}$, relative to control measurements $\left(\mathrm{T}_{2}\right.$; ANOVA, $\left.F_{1,37}=6.2, \mathrm{p}=0.018\right)$, while unfed fragments showed no significant increase in reflectance $(\%)$ between $\mathrm{T}_{0}$ and $\mathrm{T}_{1}$ (ANOVA, $F_{1,34}=0.6, p=0.46$; Fig. 5a). Reflectance (\%) spectra from both fed and unfed fragments showed the lowest reflection in areas of absorption maxima for chl a (435-440 and $675 \mathrm{~nm}$ ), the peridinin-chlorophyllprotein complex $(540 \mathrm{~nm})$, and $\mathrm{chl} c(630-635 \mathrm{~nm}$; Fig. 5b,c).

\subsection{Gross photosynthesis}

Areal gross photosynthesis rates measured at high incident photon irradiance of $E_{d}=2400 \mu \mathrm{mol}$ photons $\mathrm{m}^{-2} \mathrm{~s}^{-1}$ were not statistically different between measurements performed at any time point or feeding treatment $\left(\right.$ ANOVA, $F_{2,19}=1.4$,

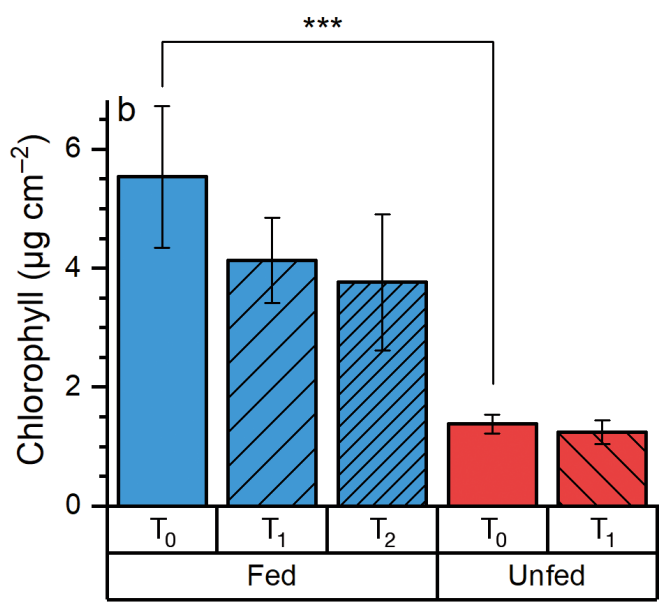

Fig. 3. (a) Mean Cladocopium sp. density, (b) mean chlorophyll density, and (c) cell-specific chlorophyll content in fed and unfed Pocillopora sp. before $\left(\mathrm{T}_{0}\right)$ and after thermal stress $\left(\mathrm{T}_{1}-\mathrm{T}_{2}\right)$. Columns with error bars indicate means \pm $\mathrm{SE}(\mathrm{n}=4-5)$, and asterisks refer to differences at ${ }^{*} \mathrm{p}<0.05$ and ${ }^{* * *} \mathrm{p}<<0.01$

$\mathrm{p}=0.26$ for fed, and $F_{1,22}=1.1, \mathrm{p}=0.30$ for unfed; Fig. 6a).

For fed fragments, mean gross photosynthesis per cell was 1.4 times higher at $\mathrm{T}_{1}$ relative to control fragments at $T_{0}$. No difference was observed for fed fragments between $T_{1}$ and $T_{2}$. For unfed fragments, gross photosynthesis per cell was 1.1-fold higher for $T_{1}$ compared to $\mathrm{T}_{0}$ (Fig. 6b). Unfed fragments had an overall $~ 0.25-0.3$ times higher gross photosynthesis per cell compared to fed fragments across all time points (Fig. 6b).

Gross photosynthesis versus photon irradiance curves were corrected for the actual in vivo photon scalar irradiance measured with microsensors at the coral tissue surface for the individual treatments and time points (see Section 2.3 for details). Areal gross photosynthesis for unfed control corals reached saturation level (maximal photosynthesis; $\mathrm{P}_{\max }$ ) at $\mathrm{P}_{\max }=0.52 \pm 0.01$ (SE) nmol $\mathrm{O}_{2} \mathrm{~cm}^{-2} \mathrm{~s}^{-1}$ ( $\alpha$ [photosynthetic efficiency] $=0.0013 \pm 0.0006[\mathrm{SE}] ; \mathrm{T}_{0}$ ) at a photon scalar irradiance of $\sim 2150 \mu \mathrm{mol}$ photons $\mathrm{m}^{-2} \mathrm{~s}^{-1}$ (Fig. 7b). Fed control corals reached a similar saturation level at $\mathrm{P}_{\max }=0.53 \pm 0.01 \mathrm{nmol} \mathrm{O} \mathrm{Cm}^{-2} \mathrm{~s}^{-1}$ $\left(\alpha=0.0020 \pm 0.0011 ; \mathrm{T}_{0}\right)$ at a photon scalar irradiance of $\sim 2300 \mu \mathrm{mol}$ photons $\mathrm{m}^{-2} \mathrm{~s}^{-1}$ (Fig. 7a). $\mathrm{P}_{\max }$ for 

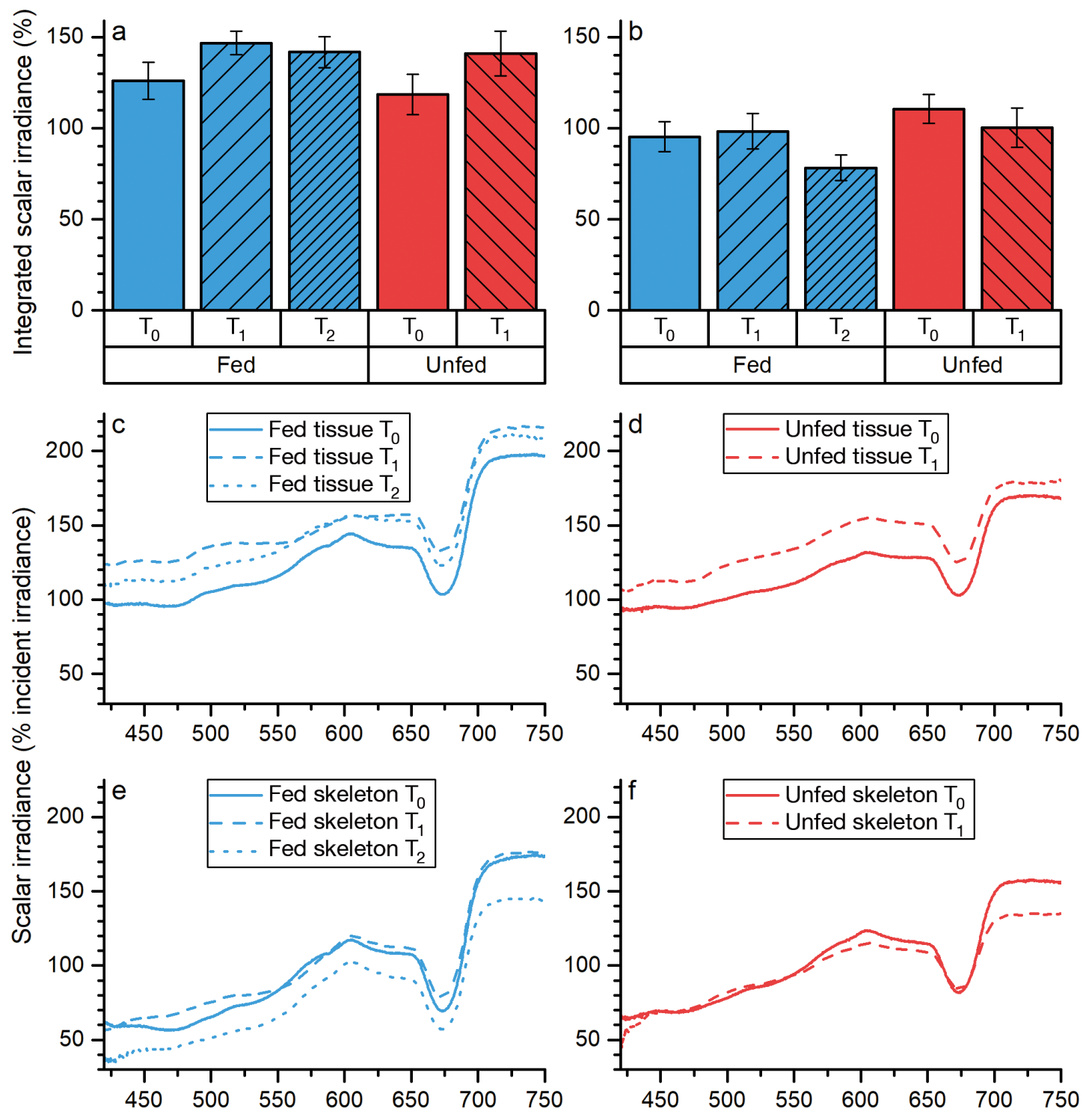

Wavelength $(\mathrm{nm})$

Fig. 4. (a,b) Scalar irradiance (integrated over 425-700 nm) in percent of downwelling irradiance at (a) the coral tissue surface and (b) the coral tissue-skeleton interface of fed and unfed Pocillopora sp. during thermal stress, and (c-f) spectral scalar irradiance (in percent of the incident downwelling irradiance) measured in (c,d) polyp surface tissue and (e,f) at the coral skeleton-tissue interface of $(\mathrm{c}, \mathrm{e})$ fed and $(\mathrm{d}, \mathrm{f})$ unfed fragments of Pocillopora sp. during thermal stress. Columns with error bars and all spectra indicate means \pm SE $(n=10-15)$ for each time point per treatment (relative error of $20-50 \%$ for all spectra; $\mathrm{c}-\mathrm{f})$. Wavelengths below $425 \mathrm{~nm}$ were omitted due to high amounts of stray light in the spectrometer. Note that error bars in panels c-f are omitted for clarity, and the y-axes start at $30 \%$

unfed corals dropped to $0.44 \pm 0.02 \mathrm{nmol} \mathrm{O}_{2} \mathrm{~cm}^{-2} \mathrm{~s}^{-1}$ $\left(\alpha=0.0007 \pm 0.0007 ; T_{1}\right)$, while $P_{\max }$ for fed corals increased to $0.67 \pm 0.03 \mathrm{nmol} \mathrm{O} \mathrm{cm}^{-2} \mathrm{~s}^{-1}(\alpha=0.0019$ $\pm 0.0017 ; \mathrm{T}_{1}$ ) after $3 \mathrm{~d}$ of thermal stress, under a photon scalar irradiance of $\sim 2600 \mu \mathrm{mol}$ photons $\mathrm{m}^{-2} \mathrm{~s}^{-1}$ (Fig. 7b). $\mathrm{P}_{\max }$ decreased to $0.50 \pm 0.03 \mathrm{nmol}$ $\mathrm{O}_{2} \mathrm{~cm}^{-2} \mathrm{~s}^{-1}\left(\alpha=0.0012 \pm 0.0014 ; \mathrm{T}_{2}\right)$ for fed corals after $8 \mathrm{~d}$ of thermal stress and reached saturation at $\sim 2200 \mu \mathrm{mol}$ photons $\mathrm{m}^{-2} \mathrm{~s}^{-1}$ (Fig. 7a).

\subsection{Temperature measurements}

The TBL thickness of Pocillopora sp. was 746 $\pm 67(\mathrm{SE}) \mu \mathrm{m}$ for fed fragments and $617 \pm 37 \mu \mathrm{m}$ for unfed fragments under an incident photon irradiance of $\mathrm{E}_{\mathrm{d}}=2400 \mu \mathrm{mol}$ photons $\mathrm{m}^{-2} \mathrm{~s}^{-1}$ and a flow velocity of $\sim 0.25 \mathrm{~cm} \mathrm{~s}^{-1}$ (Fig. 8a). For both fed and unfed fragments, surface heating at $\mathrm{T}_{0}$ reached a $\Delta \mathrm{T}$ of $0.19 \pm 0.02(\mathrm{SE})^{\circ} \mathrm{C}$ and 0.17 

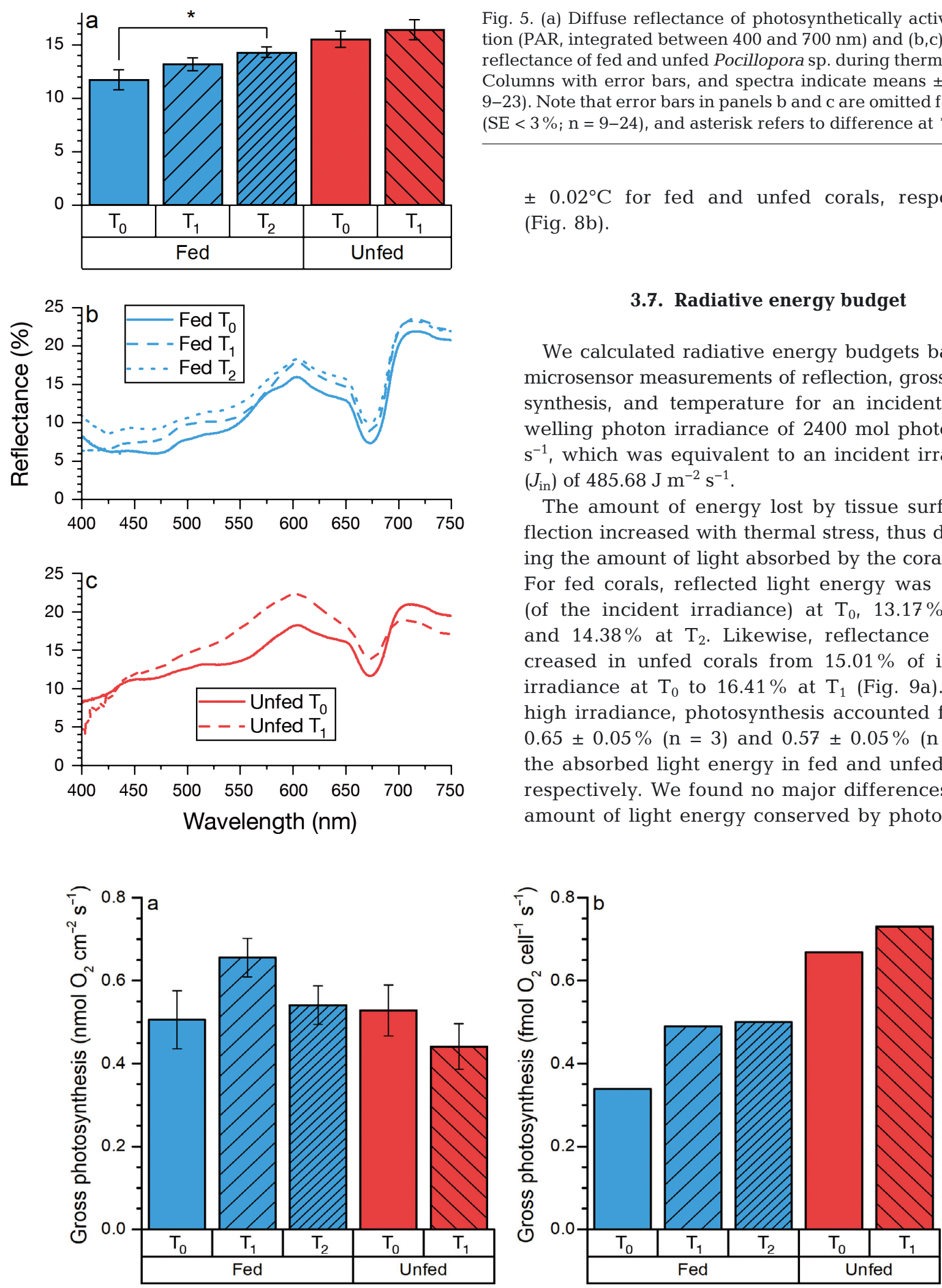

Fig. 6. (a) Areal gross photosynthesis of fed and unfed specimens of Pocillopora sp. under thermal stress measured at $2400 \mu \mathrm{mol}$ photons $\mathrm{m}^{-2} \mathrm{~s}^{-1}$, averaged for each time point per treatment. Columns with error bars indicate means $\pm \mathrm{SE}(\mathrm{n}=5-12)$.

(b) Cell-specific gross photosynthesis in fed and unfed Pocillopora sp. for each treatment and time point
Fig. 5. (a) Diffuse reflectance of photosynthetically active radiation (PAR, integrated between 400 and $700 \mathrm{~nm}$ ) and $(\mathrm{b}, \mathrm{c})$ spectral reflectance of fed and unfed Pocillopora sp. during thermal stress. Columns with error bars, and spectra indicate means $\pm \mathrm{SE}(\mathrm{n}=$ 9-23). Note that error bars in panels b and c are omitted for clarity $(\mathrm{SE}<3 \% ; \mathrm{n}=9-24)$, and asterisk refers to difference at ${ }^{*} \mathrm{p}<0.05$

$\pm 0.02^{\circ} \mathrm{C}$ for fed and unfed corals, respectively (Fig. 8b).

\subsection{Radiative energy budget}

We calculated radiative energy budgets based on microsensor measurements of reflection, gross photosynthesis, and temperature for an incident downwelling photon irradiance of $2400 \mathrm{~mol}$ photons $\mathrm{m}^{-2}$ $\mathrm{s}^{-1}$, which was equivalent to an incident irradiance $\left(J_{\text {in }}\right)$ of $485.68 \mathrm{~J} \mathrm{~m}^{-2} \mathrm{~s}^{-1}$.

The amount of energy lost by tissue surface reflection increased with thermal stress, thus decreasing the amount of light absorbed by the coral tissue. For fed corals, reflected light energy was $11.72 \%$ (of the incident irradiance) at $\mathrm{T}_{0}, 13.17 \%$ at $\mathrm{T}_{1}$, and $14.38 \%$ at $\mathrm{T}_{2}$. Likewise, reflectance (\%) increased in unfed corals from $15.01 \%$ of incident irradiance at $\mathrm{T}_{0}$ to $16.41 \%$ at $\mathrm{T}_{1}$ (Fig. 9a). Under high irradiance, photosynthesis accounted for only $0.65 \pm 0.05 \%(\mathrm{n}=3)$ and $0.57 \pm 0.05 \%(\mathrm{n}=2)$ of the absorbed light energy in fed and unfed corals, respectively. We found no major differences in the amount of light energy conserved by photosynthe- 

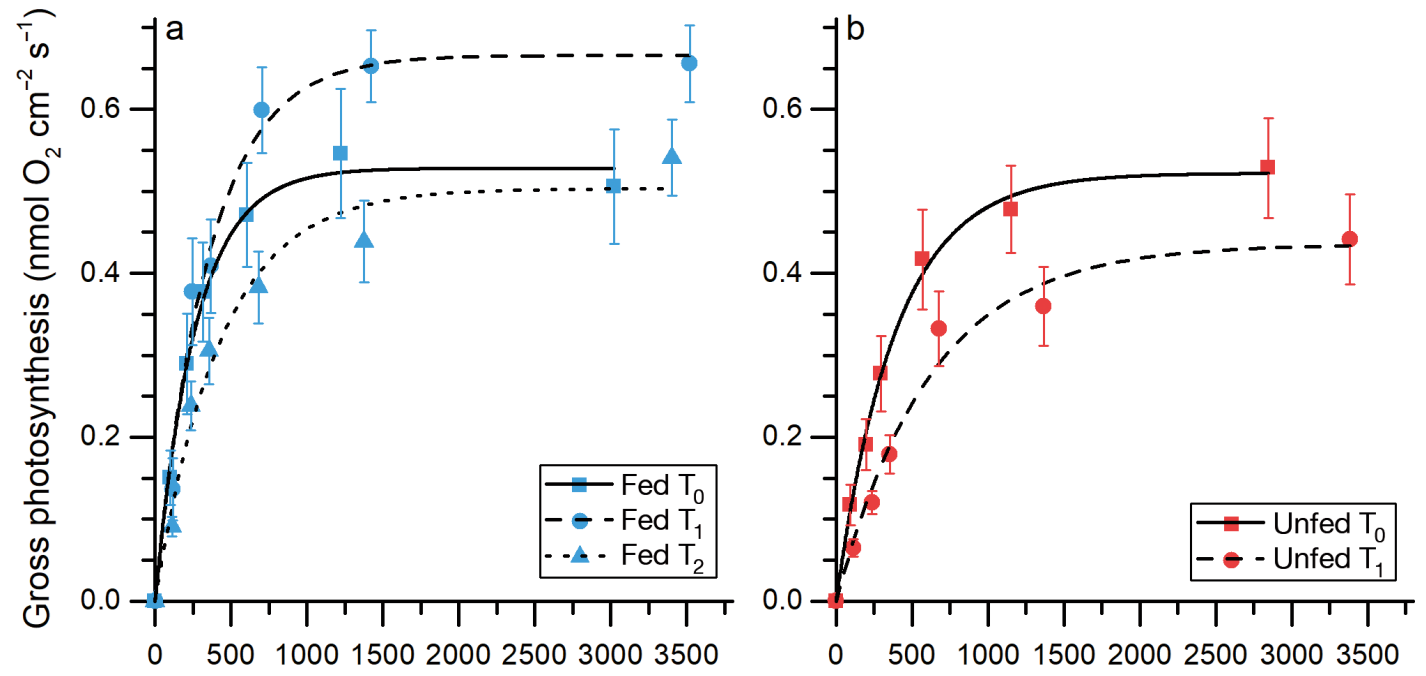

Photon scalar irradiance ( $\mu \mathrm{mol}$ photons $\mathrm{m}^{-2} \mathrm{~s}^{-1}$ )

Fig. 7. Gross photosynthesis versus photon scalar irradiance (photosynthetically active radiation, PAR, 400-700 nm) curves for (a) fed and (b) unfed fragments of Pocillopora sp. under thermal stress. Curves represent curve fits of an exponential model (Webb et al. 1974; $\mathrm{R}^{2}>$ 0.97). The light levels represent the actual amount of photons available for the individual time point and treatment by multiplying the downwelling irradiance with the local PAR enhancement obtained from the respective integrated scalar irradiance values (see Fig. 4a). Error bars indicate \pm SE of the mean $(n=5-12)$
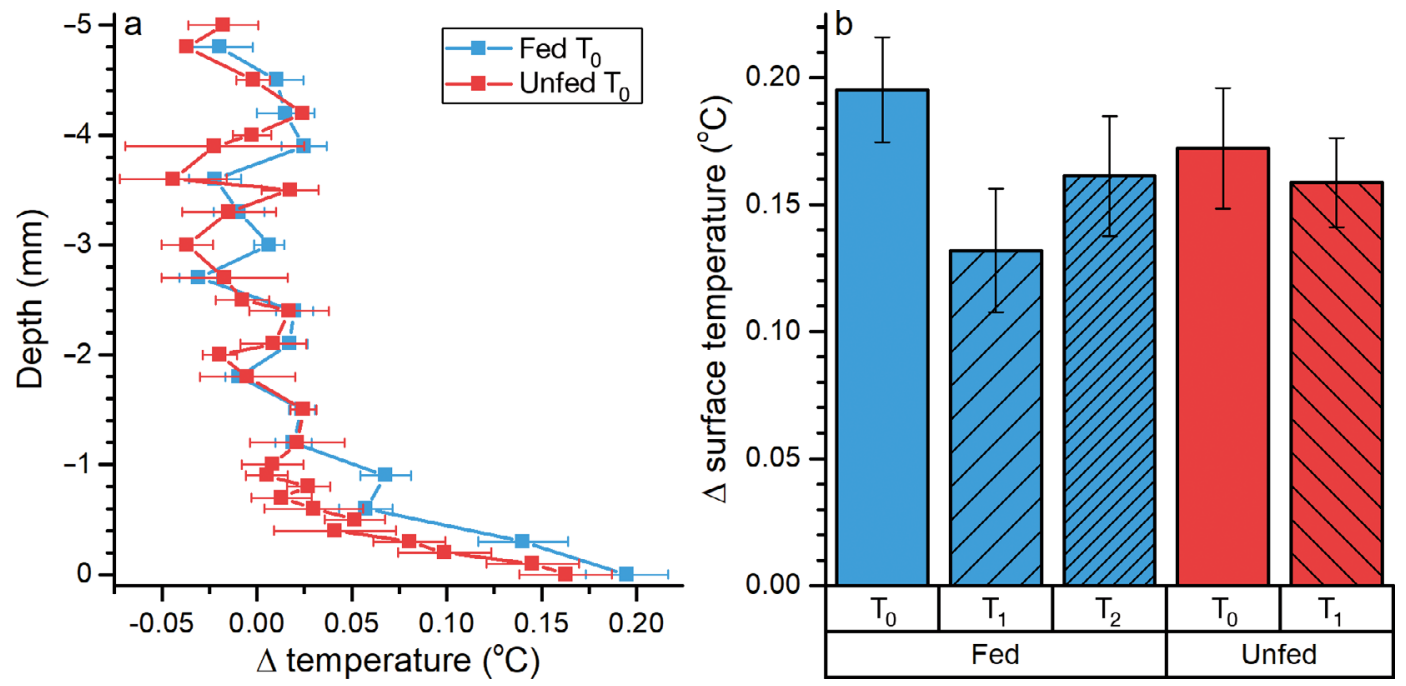

Fig. 8. (a) Temperature profiles measured towards the tissue surface of fed and unfed control fragments of Pocillopora sp. (at time point $\mathrm{T}_{0}$, see $\mathrm{T}_{1}-\mathrm{T}_{2}$ in Fig. $\mathrm{S} 3$ in the Supplement). The $x$-axis shows the temperature difference between the coral tissue surface $(0 \mathrm{~mm})$ and the mean ambient water temperature under a downwelling photon irradiance of $2400 \mu \mathrm{mol}$ photons $\mathrm{m}^{-2}$ $\mathrm{s}^{-1}$. Symbols with error bars indicate means $\pm \mathrm{SE}(\mathrm{n}=9-15)$. (b) Mean temperature differences between the coral polyp tissue surface and the ambient water at $2400 \mu \mathrm{mol}$ photons $\mathrm{m}^{-2} \mathrm{~s}^{-1}$. Columns with error bars indicate means \pm SE (n = 9-15)

sis, $J_{\mathrm{PS}}$, before and after thermal stress in either fed or unfed fragments (Fig. 9b), and heat dissipation, $J_{\mathrm{H}}$, thus accounted for $>99 \%$ of the absorbed energy dissipation in both fed and unfed fragments under high irradiance (Fig. 9b).

We calculated a theoretical radiative energy budget for a range of incident photon irradiance levels (from 80 to $2400 \mu \mathrm{mol}$ photons $\mathrm{m}^{-2} \mathrm{~s}^{-1}$ ) based on detailed gross photosynthesis measurements on control fragments performed at these light levels (see Section 2.2.). These extrapolated radiative energy budgets indicated that an increasing amount of light energy could be conserved by photosynthesis in both fed and unfed fragments, as the incident irradiance decreased, and light saturation of photosynthesis was alleviated (Fig. 10). In 


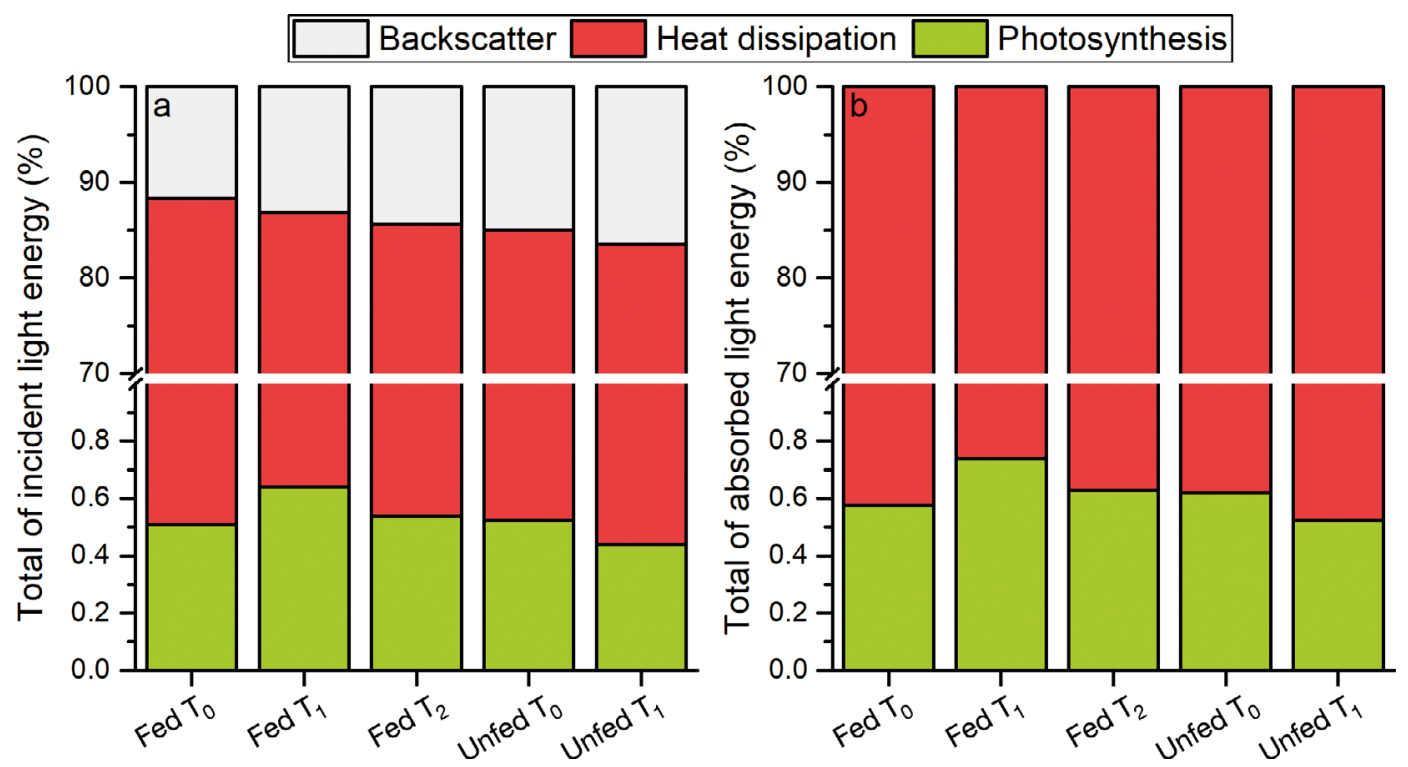

Fig. 9. Radiative energy budget of fed and unfed Pocillopora sp. under thermal stress in percent of (a) total incident and (b) total absorbed light energy under high downwelling photon irradiance of $2400 \mu \mathrm{mol}$ photons $\mathrm{m}^{-2} \mathrm{~s}^{-1}$. Gray bars indicate the amount of reflected light energy, red bars indicate the amount of light energy dissipated as heat, and green bars indicate amount of light energy conserved by photosynthesis. Note breaks in $y$-axes

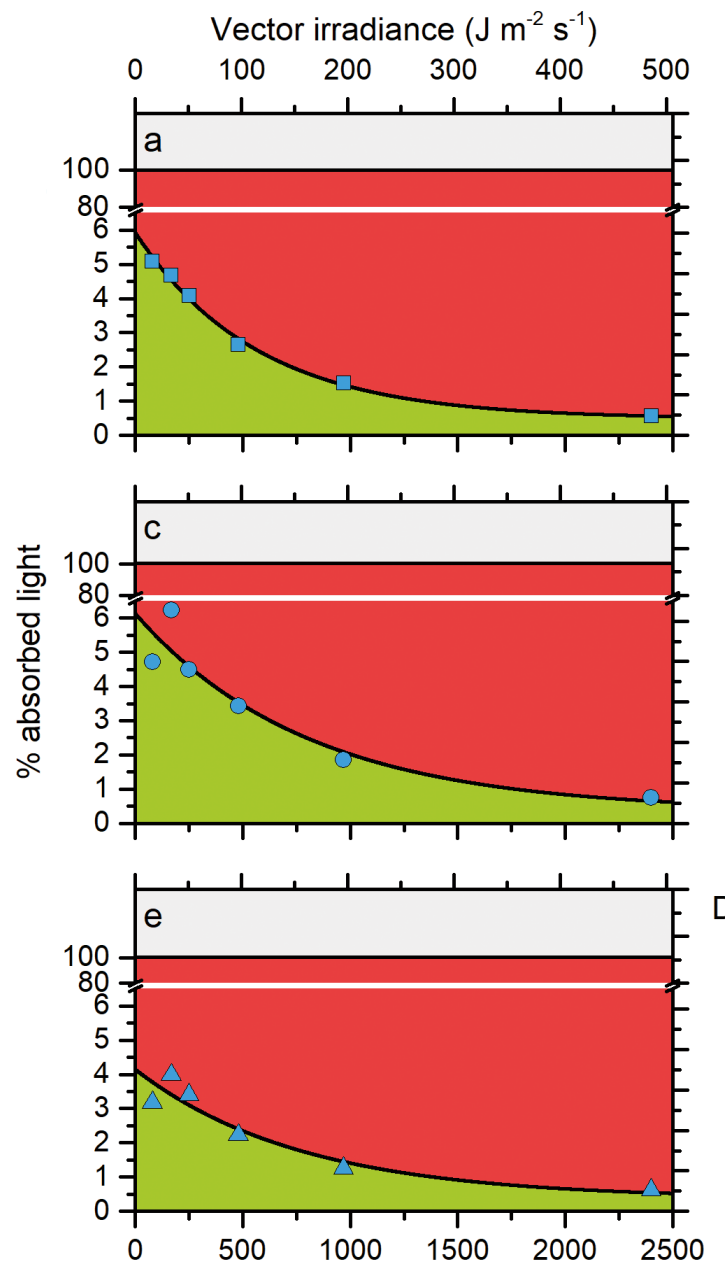

Downwelling irradiance ( $\mu \mathrm{mol}$ photons $\mathrm{m}^{-2} \mathrm{~s}^{-1}$ )

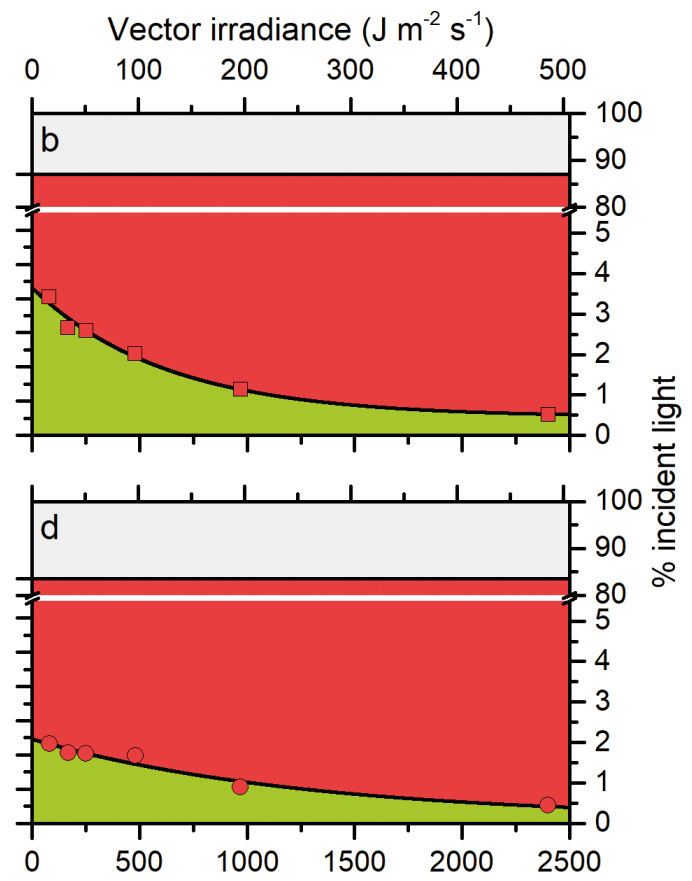

Downwelling irradiance ( $\mu \mathrm{mol}$ photons $\mathrm{m}^{-2} \mathrm{~s}^{-1}$ )

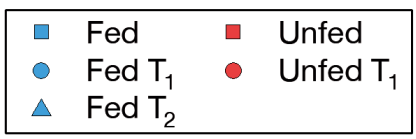

Fig. 10. Calculated energy budgets in percent of total absorbed light energy and in percent of total incident light energy for $(\mathrm{a}, \mathrm{c}, \mathrm{e})$ fed and $(\mathrm{b}, \mathrm{d})$ unfed Pocillopora sp. without thermal stress $\left(\mathrm{T}_{0}\right)$. Gray areas indicate the amount of reflected light energy, red areas indicate the amount of light energy dissipated as heat, and green areas indicate amount of light energy conserved by photosynthesis. Note breaks in $y$-axes 
fed fragments of Pocillopora sp., the highest amount of photosynthetic energy use, i.e. about $5-6 \%$ of absorbed irradiance, was found at $80 \mu \mathrm{mol}$ photons $\mathrm{m}^{-2} \mathrm{~s}^{-1}$, while unfed Pocillopora sp. reached about $4 \%$ at $\mathrm{T}_{0}$. Corals from both treatments experienced an exponential decrease in photosynthetic energy quenching at higher irradiances and reached the lowest amount of $0.5 \%$ for fed and $0.6 \%$ for unfed at $2400 \mu \mathrm{mol}$ photons $\mathrm{m}^{-2} \mathrm{~s}^{-1}$. Photosynthetic use of absorbed light decreased to about $2.5 \%$ of absorbed light energy for unfed fragments after $3 \mathrm{~d}$ of thermal stress $\left(\mathrm{T}_{1}\right)$, while fed fragments remained unaffected by thermal stress for $8 \mathrm{~d}\left(\mathrm{~T}_{2}\right)$ before photosynthetic energy quenching dropped to about $4 \%$ (Fig. 10).

\section{DISCUSSION}

In this study, we present the first comparison of closed radiative energy budgets for heterotrophically fed and unfed specimens of the symbiont-bearing coral Pocillopora sp. We investigated changes in ratios of photosynthesis and heat generation related to thermal stress and found that although both fed and unfed corals responded to thermal stress by bleaching, fed Pocillopora sp. appeared more resilient to thermal stress, as they were able to remain photosynthetically competent for $5 \mathrm{~d}$ longer than unfed specimens.

\subsection{Photosynthesis and thermal stress}

When comparing across all time points, the areal gross photosynthesis in fed corals was about 1.2 times higher than in unfed corals (Fig. 6a). Furthermore, both relative electron transport rate (rETR) and the effective quantum yield of PSII [Y(II)] were higher at all irradiance levels in fed relative to unfed corals pre- and post-bleaching (Fig. 2), which is similar to previous studies (e.g. Ferrier-Pagès et al. 2010). Feeding corals has been shown to alleviate photodamage of symbiotic dinoflagellates, where unfed corals showed a decline in their nocturnal recovery rates of PSII relative to fed corals, and thus suffered more from chronic photoinhibition (Borell \& Bischof 2008, Borell et al. 2008).

Additionally, both rETR and $Y($ II) in fed corals increased with thermal stress $\left(\mathrm{T}_{2}\right.$; Fig. 2$)$, which stands in contrast to the results from previous studies (e.g. Ferrier-Pagès et al. 2010). Thermal stress usually inhibits the photosynthetic capabilities of aquatic photo- trophs, as increased temperature leads to degradation of enzymes crucial for sustaining electron transport in the photosystems (Falkowski \& Raven 2007). However, our corals showed little to no decline in photosynthetic rates when exposed to thermal stress, and cell-specific photosynthesis rates of Cladocopium sp. actually increased in both fed and unfed corals (Fig. 6b). While this measured increase in rETR and Y(II) remains unclear, we speculate that several factors have impacted the performance of individual cells leading to an overall short-term enhancement of their photosynthetic performance. Although symbiont densities steadily decreased under thermal stress (Fig. 3a), the chlorophyll content per cell and areal gross photosynthesis did not significantly change pre- and postbleaching in the individual feeding treatment (Figs. 3c \& 6a). High dinoflagellate cell densities $\left(>1 \times 10^{6}\right.$ cells $\mathrm{cm}^{-2}$ ) can lead to algal self-shading (Enriquez et al. 2005), and thus reduce photosynthesis in deeper tissue layers due to high light attenuation. Loss of dinoflagellates during coral bleaching can initially alleviate such self-shading effects, leading to enhanced light availability with fewer symbiont cells and potential higher photosynthetic rates (Enriquez et al. 2005). Such light enhancement was demonstrated in our scalar irradiance measurements at the coral tissue surface, which increased from $120-130 \%$ of the incident downwelling irradiance for both fed and unfed corals pre-bleaching $\left(\mathrm{T}_{0}\right)$ up to $140-145 \%$ of incident downwelling irradiance at the coral tissue surface after $3 \mathrm{~d}$ of thermal stress ( $\mathrm{T}_{1}$; Fig. $4 \mathrm{a}$ ). Such enhancement of scalar irradiance in coral tissue surface is common in bleached corals, and enhancements of up to $200 \%$ have previously been measured in polyp surface tissue of bleached Pocillopora sp. (Wangpraseurt et al. 2017a). Although the thin tissue of Pocillopora sp. did not exhibit strong light gradients compared to more thick-tissued corals (Wangpraseurt et al. 2012), the scalar irradiance at the tissue-skeleton interface in polyp corallites was slightly lower compared to surface layers (95\% of incident irradiance in fed, and $110 \%$ in unfed, $\mathrm{T}_{0}$; Fig. $4 \mathrm{~b}$ ). This attenuation became even more apparent post-bleaching, as scalar irradiance at the tissue-skeleton interface in corals from both treatments further decreased $\left(100 \%\right.$ in unfed $\mathrm{T}_{1}$ and $78 \%$ in fed $\mathrm{T}_{2}$; Fig. $4 \mathrm{~b}$ ). The reduced light attenuation during bleaching could be caused by the presence of endolithic microbes residing in the coral skeleton decreasing skeleton backscatter in certain regions of the light spectrum (Fig. $4 ;$ compare $\mathrm{T}_{1}$ in panels $\mathrm{c}$ and $\mathrm{f}$, and $\mathrm{T}_{2}$ in panels $\mathrm{b}$ and $\mathrm{d}_{\text {; Fork \& }}$ Larkum 1989, Magnusson et al.(2007). However, no such endoliths appeared present to the naked eye, 
and the role of endolithic phototrophs was not further investigated.

Local enhancement in scalar irradiance at the coral tissue surface, and thus alleviation of self-shading, increased cell-specific photosynthetic rates by about a factor of 1.1 in unfed corals, and 1.5 in fed corals, after thermal stress $\left(\mathrm{T}_{1}-\mathrm{T}_{2}\right.$ relative to $\mathrm{T}_{0}$; Fig. $\left.6 \mathrm{~b}\right)$. However, areal gross photosynthesis differed between the 2 feeding treatments, showing an initial increase for fed corals $\left(T_{1}\right)$, while unfed corals showed immediate signs of thermal stress with lowered areal gross photosynthesis (compare $T_{1}$ in fed and unfed, Fig. 6a).

Furthermore, since Cladocopium sp. in unfed corals barely showed any increase in cell-specific photosynthetic rate (Fig. 6b), this may indicate that resource limitation pushed the unfed corals to their metabolic threshold with few resources to spare, in contrast to fed corals. This could explain the increased rETR and $Y$ (II) found only in fed corals. Alleviation of selfshading was also evident from photosynthesis versus photon irradiance curves for fed corals, where $\mathrm{P}_{\max }$ remained constant $\left(\sim 0.50-0.52 \mathrm{nmol} \mathrm{O}_{2} \mathrm{~cm}^{-2} \mathrm{~s}^{-1}\right)$ between thermal treatments $\left(T_{2}\right.$ relative to $\left.T_{0}\right)$, while the $\alpha$-value was considerably decreased after thermal stress (Fig. 7a). With $\mathrm{P}_{\max }$ staying constant before and after thermal stress in fed corals, this indicates that fed corals were able to maintain their photosynthetic maximum but needed more light because of a decreased light utilization efficiency ( $\alpha$-value decreased).

\subsection{Temperature microenvironment}

Corals from either feeding treatment did not express any significant changes in radiative surface tissue warming $(\Delta \mathrm{T})$ as a result of thermal stress (Fig. 8b). However, variable chlorophyll fluorescence imaging data of fed corals did reveal a clear decrease in NPQ after $8 \mathrm{~d}$ at $30^{\circ} \mathrm{C}\left(\mathrm{T}_{2}\right)$ relative to the control corals $\left(\mathrm{T}_{0}\right.$, Fig. $\left.\mathrm{S} 2\right)$. Spectral reflectance was increased for bleached corals, thus reducing the amount of absorbed light energy and coral surface warming (Enriquez et al. 2005, Jimenez et al. 2012). We found the same trend of spectral reflectance steadily increasing with thermal stress in corals from both feeding treatments (Fig. 5), along with a clear negative correlation between coral spectral reflectance and symbiont density $\left(\mathrm{R}^{2}=0.99\right.$; Fig. S4). As such, the decrease in surface tissue heat exchange can be explained by the observed steady decrease in symbiont density and chlorophyll content during thermal stress (Fig. 3).

\subsection{Radiative energy budgets}

To establish radiative energy budgets for corals, we required a distinct thermal boundary layer that was not clearly observable below a photon irradiance of $2400 \mu \mathrm{mol}$ photons $\mathrm{m}^{-2} \mathrm{~s}^{-1}$ due to lower tissue surface heating at lower incident light energy. At such high irradiance, we observed that regardless of feeding status and thermal stress, all corals exhibited a similar energy budget where only about $85-88 \%$ of the incident light was absorbed, and furthermore that in all cases $>99 \%$ of the absorbed light energy was dissipated as heat (Fig. 9). Since our corals were acclimated to a photon irradiance $(400-700 \mathrm{~nm})$ of $\sim 250 \mu \mathrm{mol}$ photons $\mathrm{m}^{-2} \mathrm{~s}^{-1}$, we estimated theoretical radiative energy budgets calculated from photosynthesis data acquired at lower light levels (see Section 2.6).

Extrapolation of the radiative energy budget to lower incident irradiances showed that photosynthesis could account for up to $\sim 4$ and $\sim 5-6 \%$ of absorbed light energy in non-stressed $\left(\mathrm{T}_{0}\right)$ unfed and fed corals, respectively, under light-limiting conditions (Fig. 10a,b). In a previous study on a massive symbiont-bearing coral, Brodersen et al. (2014) showed that a nonstressed Montastrea curta performed slightly better in terms of light energy efficiency as compared to the Pocillopora sp. investigated in this study. M. curta had a maximum photosynthetic energy efficiency of $\sim 4 \%$ at $640 \mu \mathrm{mol}$ photons $\mathrm{m}^{-2} \mathrm{~s}^{-1}$ under a flow velocity of $0.4 \mathrm{~cm} \mathrm{~s}^{-1}$, while our fed Pocillopora sp. only reached a photosynthetic energy efficiency of $\sim 2 \%$ under a similar irradiance and a slightly slower flow velocity of $0.25 \mathrm{~cm} \mathrm{~s}^{-1}$. The difference in photosynthetic efficiency between Pocillopora sp. and $M$. curta might be due to differences in skeletal heat conduction (Jimenez et al. 2012), as thin-tissued branching corals such as Pocillopora sp. exhibit a higher heat conduction into the skeleton than thicktissued massive corals. TBL measured on Pocillopora sp. with a temperature microsensor revealed an average TBL thickness of $\sim 680 \mu \mathrm{m}$, whereas Brodersen et al. (2014) found a TBL thickness of $>3 \mathrm{~mm}$ for $M$. curta at similar flow conditions. The TBL thickness is controlled by coral growth form and microtopography (Jimenez et al. 2008). The small-polyped Pocillopora sp. has a rather smooth tissue surface structure compared to massive faviid corals (Wangpraseurt et al. 2017b), thus explaining the relatively thin TBL found in Pocillopora sp. (Jimenez et al. 2011). The highly complex topography and tissue organization of corals thus play a key role for the radiative energy budget and photosynthetic efficiency of corals (Lichtenberg et al. 2016). In contrast, studies on energy use 
efficiency in other highly pigmented photosynthetic systems (e.g. benthic biofilms and coral sediments) reveal low energy use efficiencies due to their more uniform topography and high optical density (AlNajjar et al. 2010, Lichtenberg et al. 2017).

Clear differences in thermal tolerance were observed from our calculated energy budgets at lower irradiance $\left(80-250 \mu \mathrm{mol}\right.$ photons $\left.\mathrm{m}^{-2} \mathrm{~s}^{-1}\right)$. Fed corals appeared unaffected by the temperature increase $3 \mathrm{~d}$ after the onset of thermal stress, whereas unfed corals expressed an immediate sign of stress via decreased photosynthetic quenching of absorbed light energy ( $4 \%$ as compared to $2-2.5 \%$; Fig. 10d). Only after an additional $5 \mathrm{~d}$ of thermal stress did fed corals also express signs of stress by decreasing their photosynthetic quenching of absorbed light energy from 5-6\% down to $\sim 4 \%$ (Fig. 10e). Such differences in thermal tolerance can have important ecological implications, since corals located in nutrient-rich environments will be more resilient to stress compared to corals growing in oligotrophic nutrient-poor environments.

We conclude that actively feeding Pocillopora sp. handled thermal stress better and maintained their energy demand, as the remaining symbionts showed increased photosynthetic rates during bleaching. How such implications of feeding behavior, symbiont densities, and photosynthesis relate to real-world thermal stress events is yet to be determined.

Acknowledgements. We thank the staff at the Scientific Center of Monaco for their excellent assistance with experimental procedures, and labor-intensive general maintenance and care of the corals for the duration of this study. The study was funded by grants from the Carlsberg Foundation (D.W., M.K.), the European Union's Horizon 2020 scheme (D.W.), a Sapere Aude Advanced Grant from the Independent Research Fund Denmark (M.K.; DFF-1323-00065B), and the Scientific Center of Monaco (part of the RTPI Nutress).

\section{LITERATURE CITED}

Ainsworth TD, Heron SF, Ortiz JC, Mumby PJ and others (2016) Climate change disables coral bleaching protection on the Great Barrier Reef. Science 352:338-342

Al-Najjar MA, de Beer D, Jorgensen BB, Kühl M, Polerecky L (2010) Conversion and conservation of light energy in a photosynthetic microbial mat ecosystem. ISME J 4: 440-449

Al-Najjar MA, de Beer D, Kühl M, Polerecky L (2012) Light utilization efficiency in photosynthetic microbial mats. Environ Microbiol 14:982-992

Anthony KRN, Hoegh-Guldberg O (2003) Variation in coral photosynthesis, respiration and growth characteristics in contrasting light microhabitats: an analogue to plants in forest gaps and understoreys? Funct Ecol 17:246-259

Baker NR (2008) Chlorophyll fluorescence: a probe of photo- synthesis in vivo. Annu Rev Plant Biol 59:89-113

* Borell EM, Bischof K (2008) Feeding sustains photosynthetic quantum yield of a scleractinian coral during thermal stress. Oecologia 157:593-601

* Borell EM, Yuliantri AR, Bischof K, Richter C (2008) The effect of heterotrophy on photosynthesis and tissue composition of two scleractinian corals under elevated temperature. J Exp Mar Biol Ecol 364:116-123

*Bou-Abdallah F, Chasteen ND, Lesser MP (2006) Quenching of superoxide radicals by green fluorescent protein. Biochim Biophys Acta 1760:1690-1695

* Bourne DG, Garren M, Work TM, Rosenberg E, Smith GW, Harvell CD (2009) Microbial disease and the coral holobiont. Trends Microbiol 17:554-562

* Brodersen KE, Lichtenberg M, Ralph PJ, Kühl M, Wangpraseurt D (2014) Radiative energy budget reveals high photosynthetic efficiency in symbiont-bearing corals. J R Soc Interface 11:20130997

Brown BE, Dunne RP (2015) Coral bleaching: the roles of sea temperature and solar radiation. In: Woodley CM, Downs CA, Bruckner AW, Porter JW, Galloway SB (eds) Diseases of coral. John Wiley \& Sons, Hoboken, NJ, p 266-283

* Chan NCS, Wangpraseurt D, Kühl M, Connolly SR (2016) Flow and coral morphology control coral surface $\mathrm{pH}$ : implications for the effects of ocean acidification. Front Mar Sci 3:10

*Edmunds PJ, Davies PS (1989) An energy budget for Porites porites (Scleractinia), growing in a stressed environment. Coral Reefs 8:37-43

* Enriquez S, Mendez ER, Iglesias-Prieto R (2005) Multiple scattering on coral skeletons enhances light absorption by symbiotic algae. Limnol Oceanogr 50:1025-1032

Falkowski PG, Raven JA (2007) Aquatic photosynthesis, $2^{\text {nd }}$ edn., Princeton University Press, Princeton, NJ

FFerrier-Pagès C, Rottier C, Beraud E, Levy O (2010) Experimental assessment of the feeding effort of three scleractinian coral species during a thermal stress: effect on the rates of photosynthesis. J Exp Mar Biol Ecol 390:118-124

Fork DC, Larkum AWD (1989) Light harvesting in the greenalga Ostreobium sp., a coral symbiont adapted to extreme shade. Mar Biol 103:381-385

* Gittins JR, D'Angelo C, Oswald F, Edwards RJ, Wiedenmann J (2015) Fluorescent protein-mediated colour polymorphism in reef corals: multicopy genes extend the adaptation/acclimatization potential to variable light environments. Mol Ecol 24:453-465

Glynn PW (1996) Coral reef bleaching: facts, hypotheses and implications. Glob Change Biol 2:495-509

*Hill R, Schreiber U, Gademann R, Larkum AWD, Kühl M, Ralph PJ (2004) Spatial heterogeneity of photosynthesis and the effect of temperature-induced bleaching conditions in three species of corals. Mar Biol 144:633-640

*Hill R, Brown CM, DeZeeuw K, Campbell DA, Ralph PJ (2011) Increased rate of D1 repair in coral symbionts during bleaching is insufficient to counter accelerated photo-inactivation. Limnol Oceanogr 56:139-146

Hoegh-Guldberg O (1999) Climate change, coral bleaching and the future of the world's coral reefs. Mar Freshw Res 50:839-866

* Hoegh-Guldberg O, Mumby PJ, Hooten AJ, Steneck RS and others (2007) Coral reefs under rapid climate change and ocean acidification. Science 318:1737-1742

* Houlbrèque F, Ferrier-Pagès C (2009) Heterotrophy in tropical scleractinian corals. Biol Rev Camb Philos Soc 84: $1-17$ 
Hughes TP, Baird AH, Bellwood DR, Card M and others (2003) Climate change, human impacts, and the resilience of coral reefs. Science 301:929-933

* Hughes TP, Kerry JT, Álvarez-Noriega M, Álvarez-Romero JG and others (2017) Global warming and recurrent mass bleaching of corals. Nature 543:373-377

Jeffrey SW, Humphrey GF (1975) New spectrophotometric equations for determining chlorophylls $a, b, c_{1}$ and $c_{2}$ in higher plants, algae and natural phytoplankton. Biochem Physiol Pflanz 167:191-194

Jimenez IM, Kühl M, Larkum AWD, Ralph PJ (2008) Heat budget and thermal microenvironment of shallow-water corals: Do massive corals get warmer than branching corals? Limnol Oceanogr 53:1548-1561

Jimenez IM, Kühl M, Larkum AW, Ralph PJ (2011) Effects of flow and colony morphology on the thermal boundary layer of corals. J R Soc Interface 8:1785-1795

Jimenez IM, Larkum AWD, Ralph PJ, Kühl M (2012) Thermal effects of tissue optics in symbiont-bearing reefbuilding corals. Limnol Oceanogr 57:1816-1825

Kaandorp JA, Lowe CP, Frenkel D, Sloot PM (1996) Effect of nutrient diffusion and flow on coral morphology. Phys Rev Lett 77:2328-2331

Kühl M, Cohen Y, Dalsgaard T, Jørgensen BB, Revsbech NP (1995) Microenvironment and photosynthesis of zooxanthellae in scleractinian corals studied with microsensors for $\mathrm{O}_{2}, \mathrm{pH}$ and light. Mar Ecol Prog Ser 117:159-172

LaJeunesse TC, Parkinson JE, Gabrielson PW, Jeong HJ, Reimer JD, Voolstra CR, Santos SR (2018) Systematic revision of Symbiodiniaceae highlights the antiquity and diversity of coral endosymbionts. Curr Biol 28:2570-2580

* Lesser MP (1996) Elevated temperatures and ultraviolet radiation cause oxidative stress and inhibit photosynthesis in symbiotic dinoflagellates. Limnol Oceanogr 41: 271-283

Lesser MP, Farrell JH (2004) Exposure to solar radiation increases damage to both host tissues and algal symbionts of corals during thermal stress. Coral Reefs 23:367-377

Lesser MP, Weis VM, Patterson MR, Jokiel PL (1994) Effects of morphology and water motion on carbon delivery and productivity in the reef coral, Pocillopora damicornis (Linnaeus): diffusion barriers, inorganic carbon limitation, and biochemical plasticity. J Exp Mar Biol Ecol 178: 153-179

Lichtenberg M, Larkum AWD, Kühl M (2016) Photosynthetic acclimation of Symbiodinium in hospite depends on vertical position in the tissue of the scleractinian coral Montastrea curta. Front Microbiol 7:230

Lichtenberg M, Brodersen KE, Kühl M (2017) Radiative energy budgets of phototrophic surface-associated microbial communities and their photosynthetic efficiency under diffuse and collimated light. Front Microbiol 8:452

Lyndby NH, Kühl M, Wangpraseurt D (2016) Heat generation and light scattering of green fluorescent protein-like pigments in coral tissue. Sci Rep 6:26599

Magnusson SH, Fine M, Kühl M (2007) Light microclimate of endolithic phototrophs in the scleractinian corals Montipora monasteriata and Porites cylindrica. Mar Ecol Prog Ser 332:119-128

* Marcelino LA, Westneat MW, Stoyneva V, Henss J and others (2013) Modulation of light-enhancement to symbiotic algae by light-scattering in corals and evolutionary trends in bleaching. PLOS ONE 8:e61492

Muscatine L, McCloskey LR, Marian RE (1981) Estimating

Editorial responsibility: Joseph Pawlik,

Wilmington, North Carolina, USA the daily contribution of carbon from zooxanthellae to coral animal respiration. Limnol Oceanogr 26:601-611

* Odum HT, Odum EP (1955) Trophic structure and productivity of a windward coral reef community on Eniwetok Atoll. Ecol Monogr 25:291-320

* Ralph PJ, Schreiber U, Gademann R, Kühl M, Larkum AWD (2005) Coral photobiology studied with a new imaging pulse amplitude modulated fluorometer. J Phycol 41: 335-342

* Revsbech NP, Jørgensen BB (1983) Photosynthesis of benthic microflora measured with high spatial resolution by the oxygen microprofile method: capabilities and limitations of the method. Limnol Oceanogr 28:749-756

* Rickelt LF, Lichtenberg M, Trampe ECL, Kühl M (2016) Fiber-optic probes for small-scale measurements of scalar irradiance. Photochem Photobiol 92:331-342

* Rodolfo-Metalpa R, Richard C, Allemand D, Bianchi CN, Morri C, Ferrier-Pagès C (2006) Response of zooxanthellae in symbiosis with the Mediterranean corals Cladocora caespitosa and Oculina patagonica to elevated temperatures. Mar Biol 150:45-55

* Thornhill DJ, Rotjan RD, Todd BD, Chilcoat GC and others (2011) A connection between colony biomass and death in Caribbean reef-building corals. PLOS ONE 6:e29535

* Veal CJ, Carmi M, Dishon G, Sharon Y and others (2010a) Shallow-water wave lensing in coral reefs: a physical and biological case study. J Exp Biol 213:4304-4312

*Veal CJ, Holmes G, Nunez M, Hoegh-Guldberg O, Osborn J (2010b) A comparative study of methods for surface area and three-dimensional shape measurement of coral skeletons. Limnol Oceanogr Methods 8:241-253

*Wangpraseurt D, Larkum AW, Ralph PJ, Kühl M (2012) Light gradients and optical microniches in coral tissues. Front Microbiol 3:316

* Wangpraseurt D, Larkum AW, Franklin J, Szabo M, Ralph PJ, Kühl M (2014a) Lateral light transfer ensures efficient resource distribution in symbiont-bearing corals. J Exp Biol 217:489-498

*Wangpraseurt D, Tamburic B, Szabo M, Suggett D, Ralph PJ, Kühl M (2014b) Spectral effects on Symbiodinium photobiology studied with a programmable light engine. PLOS ONE 9:e112809

*Wangpraseurt D, Holm JB, Larkum AW, Pernice M, Ralph PJ, Suggett DJ, Kühl M (2017a) In vivo microscale measurements of light and photosynthesis during coral bleaching: evidence for the optical feedback loop? Front Microbiol 8:59

* Wangpraseurt D, Wentzel C, Jacques SL, Wagner M, Kühl $\mathrm{M}$ (2017b) In vivo imaging of coral tissue and skeleton with optical coherence tomography. J R Soc Interface 14: 20161003

*Wangpraseurt D, Jacques S, Lyndby NH, Holm JB, FerrierPagès C, Kühl M (2019) Microscale light management and inherent optical properties of intact corals studied with optical coherence tomography. J R Soc Interface 16: 20180567

Webb WL, Newton M, Starr D (1974) Carbon dioxide exchange of Alnus rubra. Oecologia 17:281-291

Welch AJ, van Gemert MJC (2011) Optical-thermal response of laser-irradiated tissue. Springer, New York, NY

*Wiedenmann J, D'Angelo C, Smith EG, Hunt AN, Legiret FE, Postle AD, Achterberg EP (2013) Nutrient enrichment can increase the susceptibility of reef corals to bleaching. Nat Clim Chang 3:160-164

Submitted: July 23, 2018; Accepted: September 30, 2019

Proofs received from author(s): October 21, 2019 